\begin{tabular}{l} 
2. To: (Receiving Organization) \\
Distribution \\
\hline 5. Proj./Prog./Dept./Div.: \\
HANDI 2000 INTEGRATION \\
8. Originator Remarks: \\
FOR RELEASE
\end{tabular}

11. Receiver Remarks:

3. From: (Originating Organization).
SYSTEMS - FDH
6. Design Authority/Design Agent/Cog. Engr.:
DAWN E. ADAMS

3. From: (Originating Organization).

FDH

DAWN E. ADAMS
4. Related EOT No.:
N/A
7. Purchase Order No.:
N/A

9. Equip./Component No:

N/A

10. System/Bidg./Facility:

$\mathrm{N} / \mathrm{A}$

12. Major Assm. Dwg. No.:

N/A

13. Permit/Permit Application No.:

$\mathrm{N} / \mathrm{A}$

14. Required Response Date:

N/A

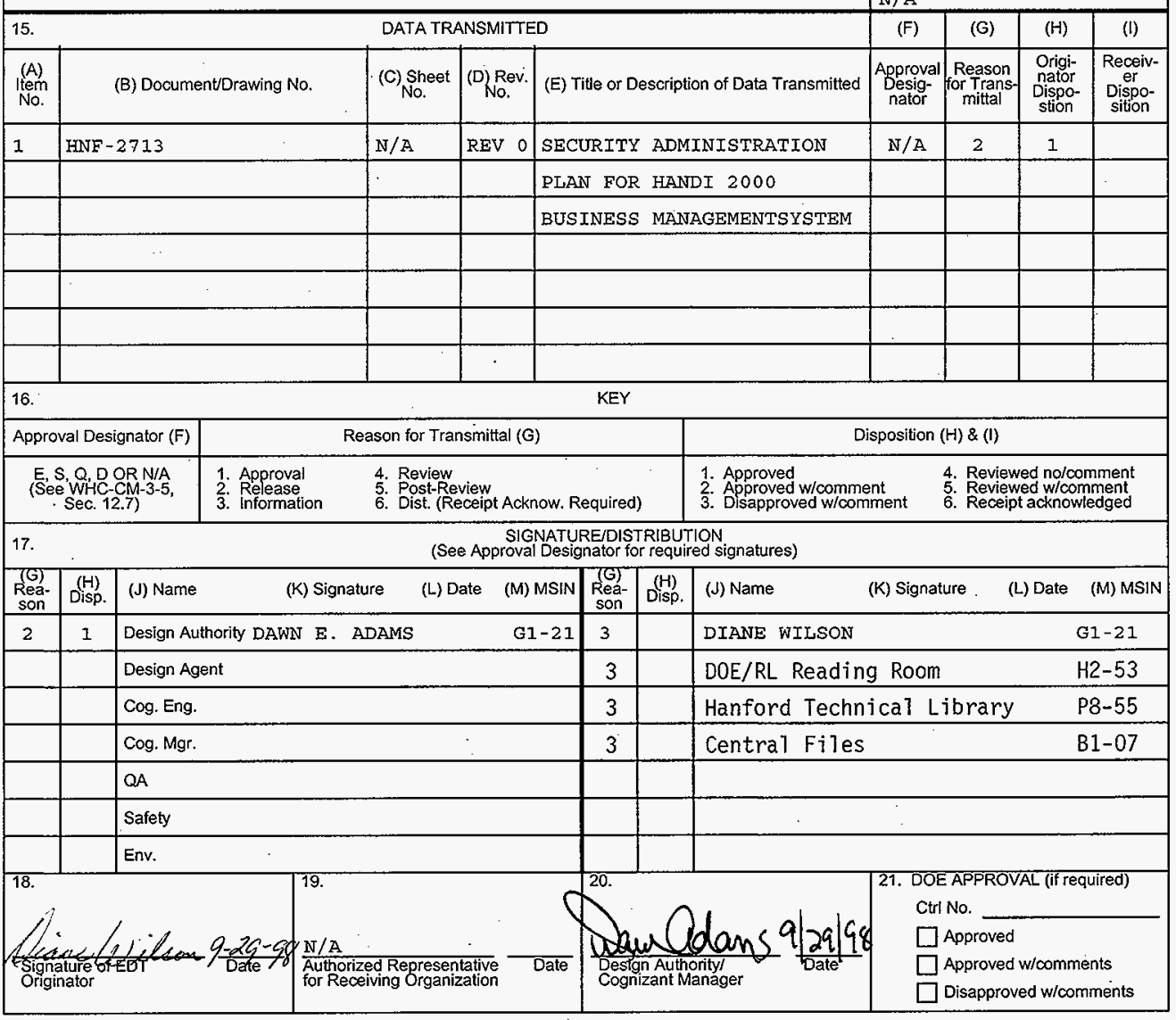




\section{SECURITY ADMINISTRATION PLAN FOR HANDI 2000 BUSINESS MANAGEMENT SYSTEM}

Dawn E. Adams, FDH

2355 Stevens MSN G1-21

Richland, WA 99352

U.S. Department of Energy Contract DE-AC06-96RL13200

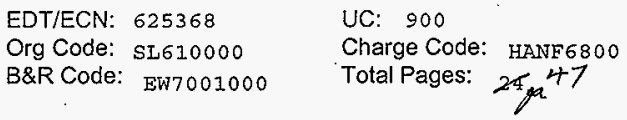

Key Words: HANDI 2000, BUSINESS MANAGEMENT, SECURITY ADMINISTRATION, H2K, BMS, PEOPLESOFT, PASSPORT, TOOLS \& METHODS, FINANCE, SUPPLY, CHEMICAL, HUMAN RESOURCES, PAYROLI, COTS

Abstract: This document encompasses and standardizes the integrated approach for security within the $\mathrm{PP}$ and $\mathrm{PS}$ applications, It also identifies the security tools and methods to be used. The security Administration Plan becomes effective as of this document's acceptance and will provide guidance through implementation efforts and, as a "living document" will support the operations and maintenance of the system.

TRADEMARK DISCLAIMER. Reference herein to any specific commercial product, process, or service by trade name, trademark, manufacturer, or otherwise, does not necessarily constitute or imply its endorsement, recommendation, or favoring by the United States Government or any agency thereof or its contractors or subcontraciuss.

Printed in the United States of America. To obtain copies of this document, contact: Document Control Services, P.O. Box 950, Mailstop H6-08, Richland WA 99352, Phone (509) 372-2420; Fax (509) 376-4989.

PassPort (PP) is a trademark of Indus Corporation.

PeopleSoft (PS) is a trademark of PeopleSoft Corporation.

UNIX is a trademark licensed exclusively through X/Open Co. Ltd.

Oracle is a trademark of Oracle Corporation. SQL is a trademark of Microsoft Corporation.
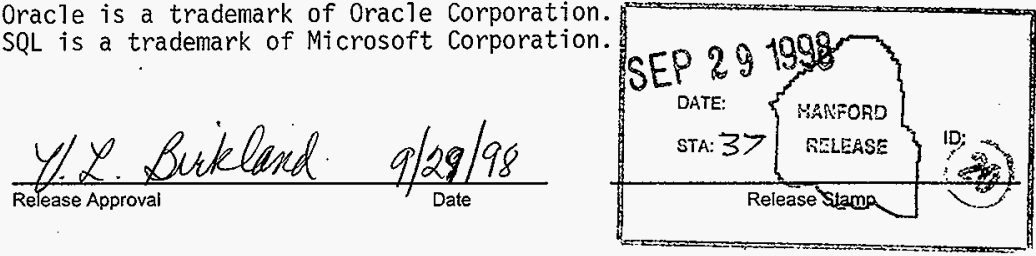

\section{Approved For Public Release}




\section{SECURITY ADMINISTRATION PLAN}

FOR

HANDI 2000

BUSINESS MANAGEMENT SYSTEM

Prepared by: Amanda McKay, LMSI Software Engineer

Prepared for: Fluor Daniel Hanford

Approved by:

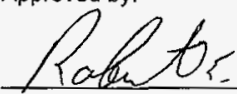

Robert E. Gates, H2K Project Director

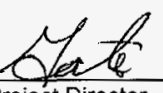

(

Steve Matiley, FDH/CIO Manager

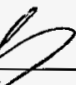

\section{y Aloms}

Dawn E. Adams, BMS Project Manager

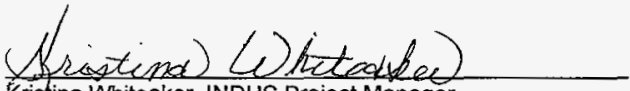

Kristina Whiteaker, INDUS Project Manager

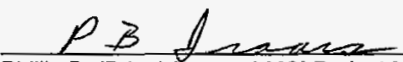

Phillip B. (Brian) Isaacs, LMSI Project Manager

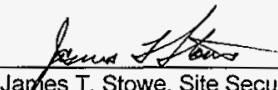

Japhes T. Stowe, Site Security Operations
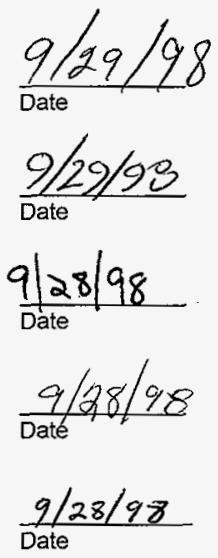

$\frac{9-29-88}{\text { Date }}$ 


\section{TABLE OF CONTENTS}

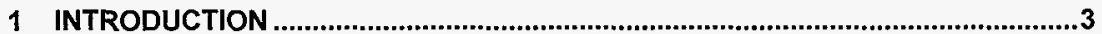

1.1 OVERVIEW

1.2 PURPOSE

1.3 SCOPE

1.4 ACRONYM DEFINITIONS

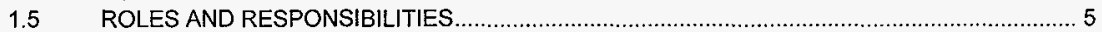

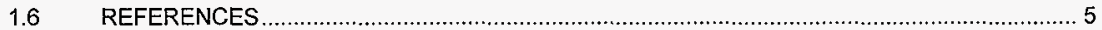

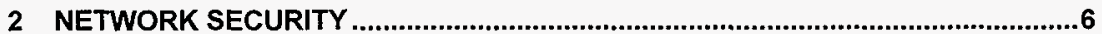

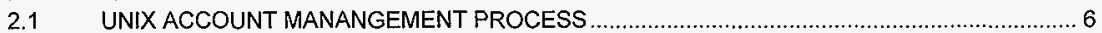

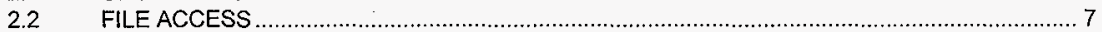

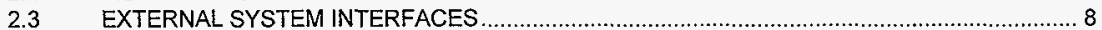

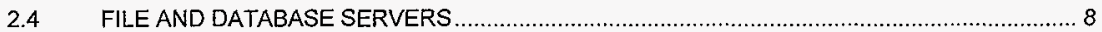

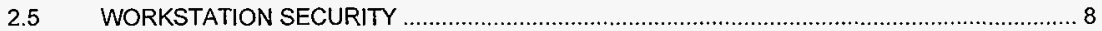

3 PASSPORT ORACLE DATABASE SECURITY ......................................................

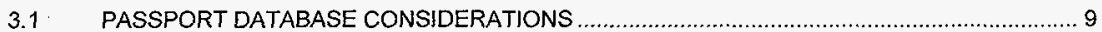

4 PEOPLESOFT RDMS DATABASE SECURITY …............................................11

4.1 PEOPLESOFT DATABASE CONSIDERATIONS ………............................................... 12

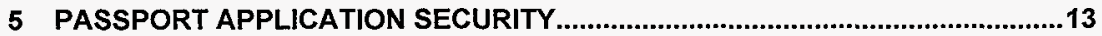

5.1 PASSPORT APPLICATION CONSIDERATIONS

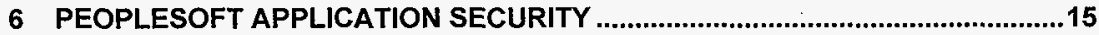

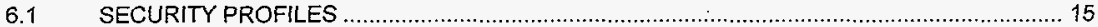

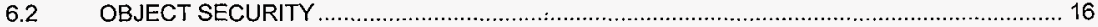

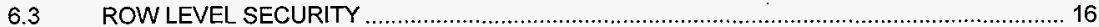

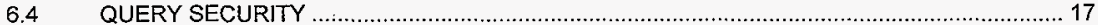

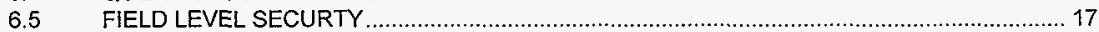

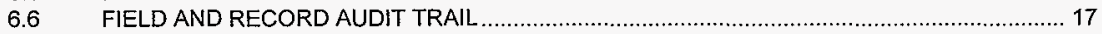

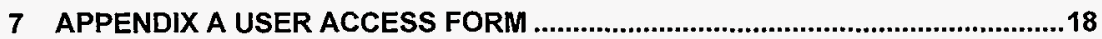

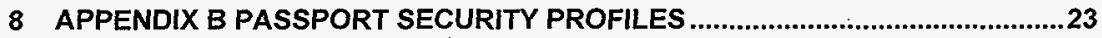

9 APPENDIX C PEOPLESOFT HR/PAYROLL/TRAINING SECURITY PROFILES .42 


\section{INTRODUCTION}

\subsection{OVERVIEW}

The Hanford Data Integration 2000 (HANDI 2000) Project will result in an integrated and comprehensive set of functional applications containing core information necessary to support the Project Hanford Management Contract (PHMC). It is based on the Commercial-Off-The-Shelf (COTS) product solution with commercially proven business processes. The COTS product solution set, of PassPort (PP) and PeopleSoft (PS) software, supports finance, supply, chemical management, human resources, and payroll activities under the current PHMC direction. The PP software is an integrated application for Accounts Payable, Contract Management, Inventory Management, Purchasing and Material Safety Data Sheets (MSDS). The PS software is an integrated application for Projects, General Ledger, Human Resources/Training, Payroll, and Base Benefits. This set of software constitutes the Business Management System (BMS) and MSDS, a subset of the HANDI 2000 suite of systems. To be referred to throughout this document as BMS.

This document provides a framework for communicating how security will be implemented and maintained across the Fluor Daniel Hanford, Incorporated (FDH) integrated components of the financial, supply, chemical management, human resource, and payroll modules. The primary objective is to minimize significant risks to the new System while ensuring access is reasonable and commensurate with job position functionality.

\subsection{PURPOSE}

This document encompasses and standardizes the integrated approach for security within the PP and PS applications. It also identifies the security tools and methods to be used. The Security Administration Plan becomes effective as of this document's acceptance and will provide guidance through implementation efforts and, as a "living document", will support the operations and maintenance of the system.

\subsection{SCOPE}

The scope of security applies to the BMS applications. The system is comprised of the following vendor product modules as databases:

\begin{tabular}{|l|l|l|l|l|}
\hline $\begin{array}{c}\text { Business } \\
\text { Management System }\end{array}$ & \multicolumn{1}{|c|}{$\begin{array}{c}\text { Vendor } \\
\text { Product }\end{array}$} & Vendor Modules & $\begin{array}{l}\text { Operating } \\
\text { System }\end{array}$ & DBMS \\
\hline Finance Management & PeopleSoft & $\begin{array}{l}\text { General Ledger } \\
\text { Projects Module }\end{array}$ & UNIX & Oracle \\
\hline Supply Management & PassPort & $\begin{array}{l}\text { Accounts Payable } \\
\text { Inventory Management } \\
\text { Contracts } \\
\text { Management } \\
\text { Purchasing }\end{array}$ & UNIX & Oracle \\
\hline Chemical Management & PassPort & MSDS & UNIX & Oracle \\
\hline Human Resources & PeopleSoft & $\begin{array}{l}\text { Human Resources } \\
\text { Training }\end{array}$ & NT & $\begin{array}{l}\text { SQL } \\
\text { Server }\end{array}$ \\
\hline Payroll & PeopleSoft & $\begin{array}{l}\text { Payroll } \\
\text { Base Benefits }\end{array}$ & $\begin{array}{l}\text { SQL } \\
\text { Server }\end{array}$ \\
\hline
\end{tabular}


HANDI 2000

DOC ITEM: Security Administration Plan HNF- 2713, Rev.0

DATE: $09 / 15 / 98$

PAGE 4 of 46

This plan will consider three levels of security requirements: the network, application layer, and the DataBase Management Systems (DBMS).

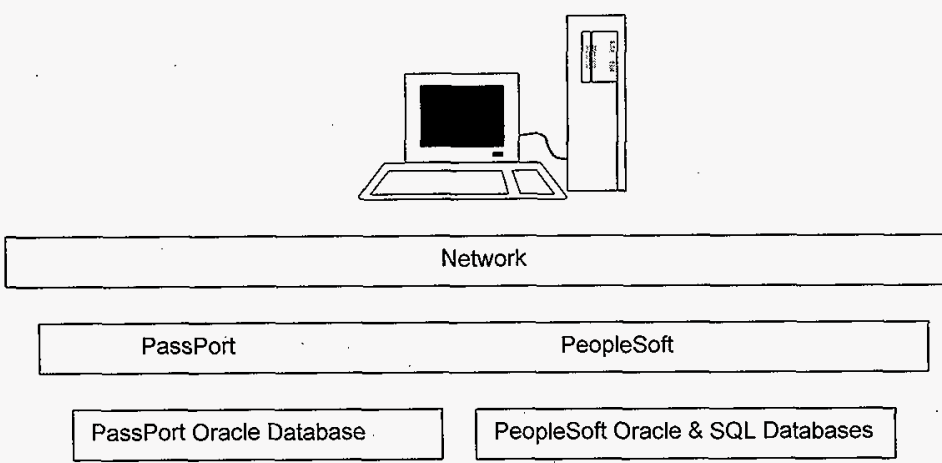

This plan does not encompass security of data that has been extracted or exported from the BMS environment. Lockheed Martin Services, Incorporated (LMSI) will not be responsible for security or valjdity of that data, however, LMSI will assist FDH in identification and/or control mechanisms for this data.

\subsection{ACRONYM DEFINITIONS}

\begin{tabular}{|l|l|}
\hline \multicolumn{1}{|c|}{ Acronym } & \multicolumn{1}{|c|}{ Definition } \\
\hline BMS & Business Management System \\
\hline COTS & Commercial Off The Shelf \\
\hline DBA & Database Administrator \\
\hline DBMS & $\begin{array}{l}\text { Database Management System - For BMS applications as follows: } \\
\text { Oracle (for PassPort Supply \& PeopleSoft Financials) } \\
\text { SQL Server (for PeopleSot Human Resources and Payroll) }\end{array}$ \\
\hline DDL & Data Definition Language \\
\hline DML & Data Manipulation Language \\
\hline FDH & Fluor Daniel Hanford, Incorporated \\
\hline H2K & HANDI 2000 \\
\hline HANDI 2000 & Hanford Data Integration Project \\
\hline HID & Hanford Identification [number] \\
\hline HLAN & Hanford Local Area Network \\
\hline HR & Human Resources \\
\hline LAN & Local Area Network \\
\hline LMSI & Lockheed Martin Services, Incorporated \\
\hline MSDS & Material Safety Data Sheets \\
\hline OPS & LMSI Operations \\
\hline PHMC & Project Hanford Management Contract \\
\hline PP & Indus PassPort software \\
\hline PS & PeopleSoft software \\
\hline SD\&I & Software Development \& Integration \\
\hline
\end{tabular}




\begin{tabular}{|l|l|}
\hline \multicolumn{1}{|c|}{ Acronym } & \multicolumn{1}{c|}{ Definition } \\
\hline TEL & Telecommunications \\
\hline TMS & Training Matrix System \\
\hline WAN & Wide Area Network \\
\hline
\end{tabular}

\subsection{ROLES AND RESPONSIBILITIES}

Within each level, the defined scope will have specific responsibilities for security implementation and maintenance.

Roles and responsibilities in the area of security will be defined for two distinct phases for the BMS system (to be referred to as "the system" from this point forward):

- Identification and implementation of security and controls in a project implementation environment;

- Maintenance and regular review of security and controls in a production environment.

\begin{tabular}{|c|c|c|}
\hline Level of Security & $\begin{array}{c}\text { Implementation } \\
\text { Responsible Organization \& } \\
\text { Position }\end{array}$ & $\begin{array}{c}\text { Production } \\
\text { Responsible Organization \& } \\
\text { Position }\end{array}$ \\
\hline Network & LMSI/OPS Network Administrator & LMSI/OPS Network Administrator \\
\hline UNIX Server Access & LMSI/OPS Password Administrator & LMSI/OPS Password Administrator \\
\hline NT Server Access & LMSI/TEL Password Administrator & LMSI/TEL Password Administrator \\
\hline PP Oracle Database & LMSI/OPS DBA & LMSI/OPS DBA \\
\hline PS Oracle Database & LMSI/OPS DBA & LMSI/OPS DBA \\
\hline PS SQL Database & LMSI/SDI DBA & LMSI/SDI DBA \\
\hline $\begin{array}{l}\text { PP Supply Application } \\
\text { (Functional) }\end{array}$ & FDH System Administrator & FDH System Administrator \\
\hline $\begin{array}{l}\text { PP Supply Application } \\
\text { (Technical) }\end{array}$ & LMSI/SDI Software Engineer & LMSI/SDI Software Engineer \\
\hline $\begin{array}{l}\text { PS Financial Application } \\
\text { (Functional) }\end{array}$ & FDH System Administrator & FDH System Administrator \\
\hline $\begin{array}{l}\text { PS Financial Application } \\
\text { (Technical) }\end{array}$ & LMSI/SDI Software Engineer & LMSI/SDI Software Engineer \\
\hline $\begin{array}{l}\text { PS HR/PR Application } \\
\text { Technical }\end{array}$ & LMSI/SDI Software Engineer & LMSI/SDI Software Engineer \\
\hline $\begin{array}{l}\text { PS HR/PR Application } \\
\text { Functional }\end{array}$ & FDH System Administrator & FDH System Administrator \\
\hline
\end{tabular}

\subsection{REFERENCES}

HNF-2584

HNF-2858

HNF -2859

HNF-PRO-592

HNF-2857

Appendix A

Appendix B

Appendix $\mathbf{C}$
Region and Database Management Plan

Backup and Recovery for HANDI 2000 Software

Disaster Recovery for HANDI 2000 Hardware and Software

Unclassified Computer Security Management Control Process

System Design Description

Security Access Form

Passport Security Profiles

Peoplesoft Security Profiles 


\section{NETWORK SECURITY}

The network is comprised of the following components:

- Communication lines across the Wide Area Network (WAN) and Local Area Network (LAN)

- Fileservers

- Database servers

- User workstations

Network and database security controls will comply with existing FDH policies and guidelines. The departments and responsible hardware owners will administer network security and audit on fileservers, workstations, and printers. Responsible LMSI organizations will ensure that policies are implemented in their appropriate areas.

Network Logon is the highest level of security for the system. Each Project Hanford Management Contract (PHMC) network user is assigned a user identification value, commonly referred to as Hanford Identification (HID) and password for authorized access to the network. Network operational procedures dictate enforcement of password changes on a regular basis and prevention of multiple unsuccessful logon attempts. These procedures will be applicable to BMS.

\subsection{UNIX ACCOUNT MANANGEMENT PROCESS}

A Password Administrator (PA) will set up a user account on the UNIX HANDI 2000 computer system. The security controls in place protect the system from unauthorized access, assure data integrity, and prevent misuse. Reference, HNF-PRO-592, Unclassified Computer Security Management Control Process, Section 5.0 guidelines. This security is necessary in order to gain entry to the PeopleSoft and PassPort applications.

\subsubsection{Password Access Controls}

The password automatically expires every 90 days. The expiration date initializes when the new user logs on the system for the first time. Passwords shall be from six to eight characters in length, with at least one non-alphabetic. The password's first character must be an alpha. There are controls established to prevent users from resetting passwords to a previous password.

User account passwords automatically expire every 90 days prompting the user to enter a new password. There are no restrictions regarding how often a password can be changed. Each time a password is changed it is encrypted to insure security.

To alert the System Administrator to possible intruder activity, a system log entry is made after five unsuccessful password entry attempts. There are scripts that generate an electronic mail message to the UNJX System Administrator that invalid attempts have taken place. The System Administrator reviews the $\log$ daily.

\subsubsection{New Accounts}

Either the Functional System Administrator or Data Owner will send an access request form to Technical Operations for a new user account to be set up on a particular system. The PA will perform the following:

- Assign the user a Unique User Identification (UID) enabling them to access all UNIX systemș for which they are approved. 
- Assign the user an unique logon identification. This is typically the Hanford Identification (HID) number prefaced by an alphabetic character.

- After the account and directory for new users are set up, a default password is assigned. The access request application will be returned to the Access Authorizer for notification that the account has been created. The application security can then be established.

- The Access Authorizer will notify the new user of the logon identification and default password and coordinate any needed training.

The PA will send the new user, via electronic mail, a Password Verification form instructing the user on the proper use of passwords. The user will forward this message back to the PA, which indicates the user has read and understands the password rules. The forwarded form and the access request form will be retained by the PA for as long as the user has access to the system. If the user does not return this form within ten working days the account is suspended and a second request is sent. If no response from the user is received within five working days, the account is deleted from the system.

\subsubsection{Delete Account}

When the Access Authorizer notifies the PA of a user termination or transfer to another on-site company, the PA will immediately suspend the user account. The account will be deleted from the UNIX system within two days of notification. The PA will use a script to delete the logon id and directories from the password account file. The PA notifies the Access Authorizer of the UNIX system of terminated users that were deleted.

\subsubsection{Change Password}

The PA will make requested changes to user password files upon request; the most common request by users is to correct forgotten passwords. The PA will change the password to a default password and send the user an electronic mail message with the receipt of request and the new password, The system will prompt the user to enter a new password the next time the user logs on. This password will be encrypted to insure security.

\subsubsection{Data Owner Account Review}

On a quarterly basis, an updated list of all users is sent to the data owner's Access Authorizer for review along with a second list indicating "LAST LOGON" by users. This list indicates the last date the user logged on the system. The Access Authorizer will send a request to the PA of any users no longer requiring access and will request the "LOGON ID" be deleted from the password account.

\subsubsection{LMSI Account Review}

The PA creates a list of all users including the last date the user logged onto the system. Users that have not logged on for 90 days or longer or have a status of "NEVER LOGGED ON" will be deleted from the system. The PA will notify the Access Authorizer of account deletions.

\subsection{FILE ACCESS}

The BMS executable files will reside on secured fileservers. LMSI will list all directories and recommend read-only access to the directories where necessary. 


\subsection{EXTERNAL SYSTEM INTERFACES}

When data is sent to systems external to BMS, the security and audit for that data becomes the responsibility of the recipient; LMSI will outline the security and audit considerations for that data. Once data has been extracted for use outside of the BMS systems (through a report, query, or interface), the security and audit for the data is no longer auditable by LMSI or BMS.

\subsection{FILE AND DATABASE SERVERS}

Physical access to fileservers will be restricted. Each server will also be password protected and have appropriate backup procedures based upon the maximum level of security required by any one segment of the integrated data. Reference HNF-2858, Backup and Recovery for HANDI 2000 Software and HNF2859, Disaster Recovery for HANDI 2000 Hardware and Software.

NOTE: The Human Resources (HR) system contains training data. When users access the Training Matrix System (TMX) via the Hanford Local Area Network (HLAN) Intranet, they will be able to access specific training information within the HR system. User level security will be managed by a 'secure' Structured Query Language (SQL) connection which will permit only approved access to HR training data.

\subsection{WORKSTATION SECURITY}

Whenever a report is generated from within the system, the default output for the file is the C:ITEMP directory. In this case, the data is no longer secure and becomes the responsibility of the person initiating the report. Each BMS user has the responsibility to abide by the FDH Computer Security Rules for closing down a "session" while away from the workstation. 


\section{PASSPORT ORACLE DATABASE SECURITY}

The environment will consist of eight Oracle database instances (regions):

- Production Region

- Acceptance Region

- Development Region

- Practice Region

- Training Region

- DataLoad Region (Temporary)

- Demo Region

- Integration Region (Temporary)

The user roles requiring differing degrees of access rights to data in these database instances are:

Network Administrator -

- Processes requests by users for access to the HLAN

- Sets up LAN user accounts with an initial password.

Server Administrator -

- Sets up UNIX password accounts to allow logon/access to Database Servers.

Functional System Administrator -

- Business function

- application administration

- manages user approvals

- access, table values

- security profiles.

Technical System Administration -

- Technical function which manages the technical aspects of the systems,

- Implements user access, table values and security profiles

Power Users -

- Personnel utilizing PP to accomplish their daily work

Periodic Users -

- Personnel who may require the PP applications to do some of their work but not necessarily on a daily basis.

- Casual Users - Personnel who may require PP appljcations on an occasional basis.

NOTE: For additional information, Reference HNF-2884, Region and Database Management Plan and HNF-2857 System Design Document.

\subsection{PASSPORT DATABASE CONSIDERATIONS}

\section{Database Logon}

Direct access to the database operating environment will be given only to individuals with the proper approval. All other users will access the database strictly through the application. Data Definition Language (DDL) privileges will be restricted to the Database Administrator (DBA). Developers may still have Data Manipulation Language (DML) privileges, but will need the DBA to make physical changes to 
HANDI 2000

DOC ITEM: Security Administration Plan HNF- 2713, Rev.0

DATE: $09 / 15 / 98$

the database structure. Reference Appendix A, User Access Form.

\section{Query tools}

Access to SQL*Plus, PS/Query, Crystal Reports and any other third party report writers will be used to perform queries. Access to these query and reporting tools will only be given to end-users once the system has stabilized, adequate training has been given and access need identified and approved. 


\section{PEOPLESOFT RDMS DATABASE SECURITY}

PS Finance consists of seven databases:

- Production

- Acceptance

- Development

- Demo

- Practice

- Training

- Audit

PS Human Resources/Payroll consists of five databases:

- Production

- Development

- Demo

- Test

- Upgrade

For additional information, refer to HNF-2884, Region and Database Management Plan.

The following defines development, maintenance and user roles -

Network Administrator -

- Processes requests by users for access to the HLAN

- Sets up LAN user accounts with an initial password.

Server Administrator -

- Sets up UNIX password accounts to allow logon/access to Database Servers.

Functional System Administrator-

- Business function

- application administration

- manages user approvals

- access, table values

- security profiles.

Technical System Administration -

- Technical function which manages the technical aspects of the systems,

- Implements user access, table values and security profiles

Power Users -

- Personnel utilizing PP to accomplish their daily work

Periodic Users -

- Personnel who may require the PP applications to do some of their work but not necessarily on a daily basis.

- Casual Users - Personnel who may require PP applications on an occasional basis. 
NOTE: For additional information, Reference HNF-2884, Region and Database Management Plan and HNF-2857 System Design Document.

The PS Tools application provides the ability to update data and to use a limited subset of the PeopleTools application. Tool access and capabilities will be implemented via the user class to which each HID user is associated. The options that are being considered for user class utilization are Nvision, Tree Manager, Process Scheduler, Process Monitor, and Query.

\subsection{PEOPLESOFT DATABASE CONSIDERATIONS}

\section{Database Logon}

Direct access to the database operating environment will be given only to individuals with the proper approval. All ather users will access the database strictly through the application. DDL privileges will be restricted to the DBA. Developers may still have DML privileges, but will need the DBA to make physical changes to the database structure.

\section{Query Tools}

SQL*Plus, ISQL, PS/Query, Crystal Reports and any other third party report writers will be used to perform queries. Access to these query and reporting tools will only be given to end-users once the system has stabilized, adequate training has been given and access need has been identified and approved. 


\section{PASSPORT APPLICATION SECURITY}

The final layer of PP security is implemented within the application itself. PP provides several alternatives for defining the degree of granularity necessary. The appropriate FDH business owners will determine the level of security required for their data. PP facilitates implementation of security with the following options:

- Security Events

- Security Event Type

- Panel

- Options

- Execute Function

- Generic Search

- Rules Based (Field level security)

- Program Defined

- Simple Code

- Custom

- Authorization Levels

- Primary Level Security

- Level Type

- Security Group

- Security Profile

\subsection{PASSPORT APPLICATION CONSIDERATIONS}

\section{Security Events}

The foundation of PP's security system is the Security Event. A Security Event is an identifier associated with the security checkpoints performed by the architecture, and in some cases application programs.

The Security Event tells what authorization should be used at the security checkpoint.

\section{Security Event Type}

Security Event Types categorize Security Events with types such as panel, option, and execute.

- Panels have Security Events associated with them to allow the client to provide update, read, or no access to each panel.

- Options are menu options and may have security events controlling who has discrete option privileges on panel menus.

- The Execute Function controls access to the action associated with the Execute Command.

\section{Authorization Levels}

Authorization levels are the different levels of activity which a user may be authorized to perform on a Security Event:

- Update

- Read-only

- None

Authorization levels are assigned to Security Events only within a Security Profile. 


\section{Primary Level Security}

Primary Level Security refers to data, which has a relationship to a global data element. This element is determined at system generation time and is typically Facility. If the value of Facility on the panel matches the default Facility for the user, then that is the user's own data. If the two values do NOT match, then the user is looking at other data. This may allow different access authorizations to be specified when a users' own Facility matches the facility associated with the data and when a user's own Facility does not match the data Facility.

\section{Level Type}

Level Type Security type determines what type of security authorizations and checking will be performed for a particular Security Event at the primary levels.

- Own/Other - grant and check for different authorization levels depending upon whether the data is the user's "own".

- Unconditional - allows authorization to be granted and checked with independence of the element and data associated with the Primary Level security.

- None - This level is not being used with this application.

\section{Security Groups}

- After Security Events, Security Groups are the next level of security. Security Groups are a logical combination of security events. A group is typically composed of related events to which a specific set of users would need the same access. The same authority will be granted later to a user or specified set of users to all the events in requested group.

\section{Security Profiles}

A Security Profile consists of a logical combination of Security Groups and/or Security Events, usually tailored to a group of users who have the same system access needs. A user can be assigned a single Security Profile, multiple Security Profiles or a combination of Security Profiles and Security Events. Typically a Security Profile is defined and assigned to a large group of users needing the same authorization levels to the same PP panels. The FDH Project Leads for Supply, Human Resources, and Payroll will finalize Security Profiles by approving the profiles. Approval will be denoted by their signatures.

\section{User Profile}

A User Profile consists of a logical combination of Security Profiles and/or Security Events which provide a user with secured system access that meets their particular job requirements. A User Profile may consist of several Security Profiles or Security Events or just one Security Profile or Security Event. If a user is associated with multiple profiles, the maximum "rights" are utilized. Each user will have their own User ID (equivalent to the UNIX user account). The Functional Administrator will assign the appropriate security profiles to individuals. FDH will ensure that appropriate training accompanies the assignment of a Security Profile to a user. For detailed information on PeopleSoft Human Resources/Payroll Operator Class Security Specifications Reference HNF - 2857 System Design Description. 
HANDI 2000

DOC ITEM: Security Administration Plan HNF. 2713, Rev.0

DATE: $09 / 15 / 98$

PAGE 15 of 46

\section{PEOPLESOFT APPLICATION SECURITY}

The final layer of PS security is implemented within the application itself. The PS application offers multiple tools and options for security. It may not be necessary to utilize all aspects of PS security. PS facilitates implementation of security with the following options:

- Operator and Operator Class Security (Security Profiles)

- Security Trees

- Object Security

- Row Level Security by:

- Project

- Analysis Group

- Ledger

- Query Security

- Field Level Security

- Field and Record Audit Trail

The following section provides details on the PS security tools. For additional application level security information, reference Appendix $B$ for Finance and Appendix $C$ for Human Resources and Payroll.

\subsection{SECURITY PROFILES}

The Technical System Administrator will maintain control of the non-production (i.e. Development and Acceptance) database regions and will assign access on an as needed basis. Functional security profiles will be utilized in the production environment.

\section{Security Profiles}

Security profiles are defined using PS Security Administrator. Each Operator Class (security profile) is defined according to the business processes that it requires access to. An individual may require a new Operator Class in order to meet a specific need, however, the decision to implement the new class will be made after proper change control approvals. Each user will require his or her own ID. The Security Administrator (Functional Administrator) will assign individuals to the appropriate Operator Classes, however, the business owner will determine which Operator Class a user will be assigned. FDH will ensure appropriate training accompanies the assignment of a security profile to a user. For detailed information on PeopleSoft BMS Financials Operator Class Security Specifications and PeopleSoft BMS HR/PR Operator Class Security Specifications Reference HNF - 2857 System Design Description

\section{Panel Security}

Panel access will be granted to users when it is needed for completing one's job assignments. This approach will provide users with only those areas that they need access to in order to fulfill the business need and reduce "menu clutter". However, all modules and panels will be accessible in a test environment.

\section{Corrective Action}

Correcting historical data is accomplished with Corrective Action. Use of the Correction action will be severely limited. Only specific users will be given full access to the Correction action in PS. This is to ensure that historical records are not updated without an adequate audit trail, and that the integrity of the data is maintained. Department users will only be given access to Correction where the business process 
HANDI 2000

DOC ITEM: Security Administration Plan HNF- 2713, Rev.0

DATE: $09 / 15 / 98$

PAGE 16 of 46

demands it and only after appropriate training has been received.

\subsection{OBJECT SECURITY}

Through Object Security, PS offers the capability to secure access to the various objects within the application. The specific objects that can be secured include import definitions, menu definitions, panel group definitions, panel definitions, query definitions, record definitions, tree definitions, and projects. in a development environment it may be desirable to limit access to some of these objects. For example, once key panels and menus have been configured for production it may be necessary to restrict who has edit capabilities over these objects. It is also possible to create object groups that represent a specific area such as the general ledger. In this manner, access can be assigned only to object groups within a user's domain.

PS also offers the ability to restrict access to an entire object type - records, panels, etc. - using the Application Designer. This serves to control access to the Application Designer functionality that handles a particular type of object.

It should be noted that it is not always necessary to employ object level security, this is especially true when the size of the project team is relatively small and the group is knowledgeable. It is not needed if all developers require access to all application definitions. Currently, Finance does not plan to use Object Security.

\subsection{ROW LEVEL SECURITY}

PS offers the capability to secure access to specific rows of data within the database based on a number of attributes: Analysis Group, Ledger, Projects, Set ID, or Business Unit. Only one Business Unit and Set ID is being implemented and therefore, unlikely there will be a need to implement any row-level-security for these areas. However with Ledgers, Projects or Analysis Groups there may be requirements for rowlevel security.

\section{Projects}

Security for the project field is based on Project Trees. Within project security, the Tree Manager can control which users have access to each project through the Tree Manager. For example, project security can limit access to only one distinct project that a particular analyst or manager supports. The requirements for project level security will not be determined until the final list of system operator profiles is complete and the business need has be defined for restricting access to information. It is also necessary to wait for the list of valid Project ID's to avoid having to duplicate efforts. Currently, Finance does not plan to use Project level security. If Project level security were to be utilized, it will be necessary to build Project Trees in the system prior to assigning trees to operator classes. 


\section{Ledgers}

Ledger Security limits access to specific Ledger Types, Ledger Groups or individual ledgers. For example, there may be a requirement to allow users access to budget ledgers without allowing them access to the actuals ledger. It is also possible to secure access to specific nVision ledgers or business units, which will ensure that users can't create nVision reports that cut across ledgers to which they shouldn't have access.

\subsection{QUERY SECURITY}

Query takes advantage of operator profiles and row level security to allow how to control what query operations a user can perform and what data they can access using Query. Query options or functions are controlled for users via their Query Profile. For example, users may be able to run existing queries but not allowed to create new ones. Query types may be limited as well as the output options (i.e. Excel, Crystal).

PS also uses Access Groups to provide a logical organization to records for user access. For example, an accounting user may have access to the Genaral Ledger Access Group (which contains all the related records for that function). Access Groups are nodes in a query tree which are buil with Tree Manager. Once a query tree has been built, users may be granted access to one or more of its Access Groups. The user can then generate queries on any tables in the Access Groups accessible to them.

Once system users and their information requirements are identified, specific levels of access and appropriate Query access will be assigned. Access Groups will be utilized as much as possible. New Access Group will be added to meet specific requirements for additional tables.

\subsection{FIELD LEVEL SECURTY}

PeopleCode can restrict access to particular fields or columns within application tables. For example, if a certain class of operator needs to be able to access certain panels, but not to view a particular field on those panels, PeopleCode can hide the field for that operator class. At this point, PS recommends this functionality not be implemented because it entails customization of the application and would have upgrades implications.

\subsection{FIELD AND RECORD AUDIT TRAIL}

Through Field and Record audit trail, PS provides the ability to maintain a full audit trail at either the field or record level. This will be provided only for those processes requiring an audit trail due to impact to on-line performance and required disk space. LMSI will be responsible for providing adequate reports and/or tools for audits where an audit has been deemed necessary. 
HANDI 2000

DOC ITEM: Security Administration Plan HNF- 2713, Rev.0

DATE: $09 / 15 / 98$

PAGE 18 of 46

\section{Appendix A User Access Form}

REQUEST FOR USER APPLICATION ACCESS DATE:

IMPORTANT NOTICE Workstation required configuration for system access must be: CASUAL USERS a minimum $486 / 33$ with $16 \mathrm{mg}$ RAM and Windows 95 installed ALL OTHERS: a minimu m Pentium 100 with $32 \mathrm{mg}$ RAM and Windows 95 installed. Install through Software Distribution.

INSTRUCTIONS (Print or Type)

- Please complete all applicable information about the person requiring access.

- Return completed forms to Security Administration G1-57.

\begin{tabular}{|l|l|l|l|l}
\hline User Name (last, first, mi) & & Cost Center \\
\hline Job Title & Work Location (bldg/area/room) & Work Phone \\
Number
\end{tabular}

Select User Access Additions/Changes; all selected user access privileges MUST be supported by the Kind of Function or Information Access Required narrative.

\section{TYPE OF USER ACCESS}

REQUEST:

口New

$\square$ Change

$\square$ Inactivate User Access

\section{PASSPORT USERS: Default Printer Address:}

$\square$ Local

ㅁ Network

Network Printer Address:

\section{Annual Access Review Only. Access must be (check one)}

$\square$ Maintained

$\square$ Upgraded

$\triangle$ Downgraded

$\square$ Deleted (no longer required)

Review Date:

Kind of Function or Information Access Required:

Business Process Owner Approval:

Date:

System Administrator Approval:

Date:

***PassPort Users Only****

\begin{tabular}{|l|l|l|l|}
\hline Function & $\begin{array}{l}\text { Approval } \\
\text { level S }\end{array}$ & $\begin{array}{l}\text { Auto-Approve } \\
\text { YeS }\end{array}$ & Comments \\
\hline Material request & & & Stock \& IIT orders (WIMS) \\
\hline $\begin{array}{l}\text { Material } \\
\text { Requisition }\end{array}$ & & & Material purchases only \\
\hline $\begin{array}{l}\text { Contract } \\
\text { Requisition }\end{array}$ & & & Contracts Only \\
\hline Buyer & & & Purchase order and Amendment threshold \\
\hline Buyer Manager & & Purchase order and Amendment threshold \\
\hline Contract Admin & & Contracts and Amendment threshold \\
\hline Contract Manager & & Contracts and Amendment threshold \\
\hline Contract Pay & & Payments Authorization only \\
\hline
\end{tabular}


HANDI 2000

DOC ITEM: Security Administration Plan HNF- 2713, Rev.0

DATE: $09 / 15 / 98$

PAGE 19 of 46

\begin{tabular}{|l|l|l|l|}
\hline Authorize & & & \\
\hline Vendor Add & & & Pending Status Only \\
\hline Vendor Update & & & System Admin function only \\
\hline A/P Manager & & & \\
\hline $\begin{array}{l}\text { A/P invoice } \\
\text { Auditor }\end{array}$ & & \\
\hline A/P Vendor & & & \\
\hline
\end{tabular}

SECURITY PROFILES - FOR SECURITY ADMINISTRATION USE ONLY.

\begin{tabular}{|l|l|}
\hline$\bullet$ & PEOPLESOFT \\
- PEOPLESOFT & PAYROLL/HUMAN \\
& RESOURCES \\
$\square \quad$ Technical System Administration & $\square$ Technical System Administration \\
$\square \quad$ Functional Administration & $\square$ PeopleSoft Panels \\
$\square \quad$ Technical Support & $\square$ Crystal Reports \\
$\square \quad$ Project Controls Group & $\square$ PeopleSoft and Crystal \\
$\square$ Accounting Lead & \\
$\square$ GL Accountant & \\
$\square \quad$ Treasury/AP Accountant & \\
$\square \quad$ Cost Accountant & \\
$\square \quad$ Funds Control Analyst & \\
$\square \quad$ Project Budget Analyst & \\
$\square \quad$ Program Analyst & \\
\hline PASSPORT & \\
AP, PURCHASING, INVENTORY, CONTRACT MANAGEMENT, CHEMICAL MANAGEMENT &
\end{tabular}


HANDI 2000

DOC ITEM: Security Administration Plan HNF- 2713, Rev.0

DATE: 09/15/98

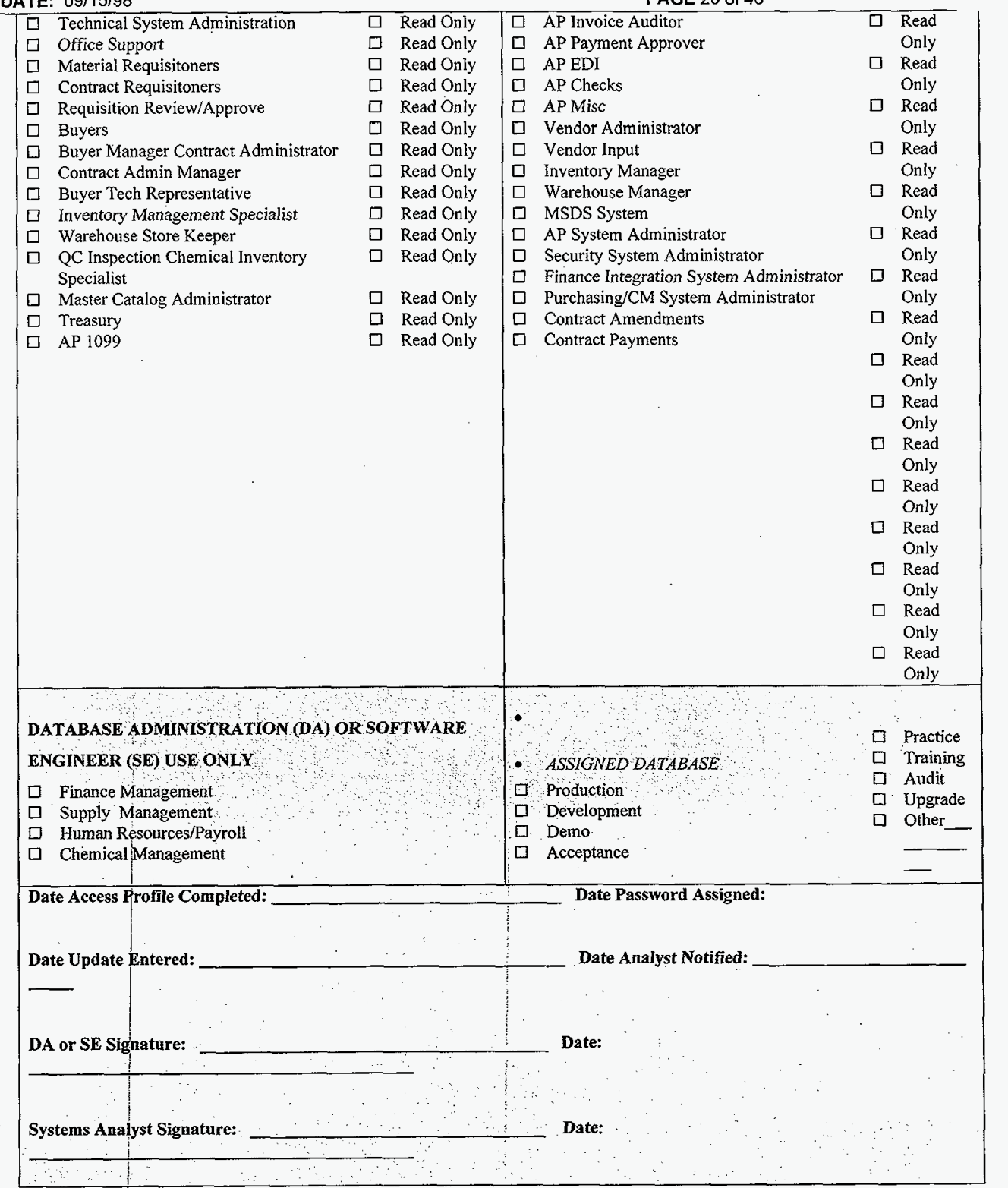


HANDI 2000

DOC ITEM: Security Administration Plan HNF- 2713, Rev.0

DATE: $09 / 15 / 98$

PAGE 21 of 46

REQUEST FOR USER ACCESS FORM COMPLETION INSTRUCTIONS

1.0 PURPOSE

This form is used to document management authorization of PHMC personnel authorized to access the HANDI 2000 project modules.

2.0 SCOPE

This form must be prepared for any PHMC employee requesting access to the HANDI 2000 project modules.

\subsection{RESPONSIBILITIES}

The employees' manager shall ensure that a new access form is prepared and submitted to Security Administration when their employee requires:

- New access

- Changes to an existing security profile

- No longer requires access

The employees' manager shall also ensure that an exiting employee completes the User Access form to terminate access as part of the exit interview process.

\subsection{PROCEDURE}

4.1 Complete all the user information in Block 1.

4.2 Complete Type of User Access Request.

4.3 Annual Access Review Only. - Leave blank and System Administrator will complete.

4.4 Complete the Kind of Function or Information Access Required information in Block 3-provide a description of how the employee will use the business functions to perform their job duties.

4.5 Business Process Owner Approval in Block 3 - leave blank and Business Process Owner will review and sign authorizing employee access.

4.6 System Administrator Approval in Block 3 - leave blank and System Administrator will review and sign authorizing employee access.

4.7 For PassPort Users only: Approval level - completed by the authorizing manager and required if the employee will be allowed to automaticaliy approve material requests or is a purchasing or contract administrator. Contract administrators should designate approval levels for contract requisitions, amendments, and payments.

4.8 For PassPort Users only: Auto Approve Indicator - complete by placing a checkmark after the appropriate approval level category.

4.9 For PassPort Users only: Approval Dollar Level - complete by identifying the maximum dollar level the employee is authorized to approve for materials requests, materials purchase orders (buyer signature authority level), contract requisitions (buyer signature authority level), contract amendment, and contract payment authority level.

4.10 Send the completed forms to Security Administration MSIN G1-57.

4.11 Completed forms received at Security Administration will be routed to the appropriate Security Administrator.

4.12 The functional Security Administrator will review the form for completeness and coordinate review and approval with the appropriate Business Process Owner.

4.13 Business Process Owner reviews and approves the form and refurns the approved form to the functional Security Administrator for assignment of the database(s) and employee security access profile(s) that match the access information provided in step 3.9.

4.14 The completed form is submitted to the Data Base Administrator for setup of the user password. PassPort users will also be assigned a UNIX account. The Security Administrator will assign the password and forward request to the UNIX account administrator (if appropriate).

4.15 If appropriate, the UNIX account administrator will assign an account to the employee and send the required UNIX account authorization form to the employee for completion. 
HANDI 2000

DOC ITEM: Security Administration Plan HNF- 2713, Rev.0

DATE: $09 / 15 / 98$

PAGE 22 of 46

4.16 The Security Administrator will notify the employee when their access is setup and ready for use. 


\section{APPENDIX B PASSPORT SECURITY PROFILES}

\begin{tabular}{|c|c|c|c|c|c|c|c|}
\hline $\begin{array}{l}\text { User } \\
\text { Role/PassPort } \\
\text { Security Profile }\end{array}$ & $\begin{array}{l}\text { User } \\
\text { Responsibility } \\
\text { Description }\end{array}$ & $\begin{array}{l}\text { PassPort } \\
\text { Access/ } \\
\text { Functions }\end{array}$ & $\begin{array}{l}\text { PassPort } \\
\text { Recommended } \\
\text { Training } \\
\text { Classes }\end{array}$ & $\begin{array}{l}\text { Training } \\
\text { Certification } \\
\text { Required for } \\
\text { Production } \\
\text { Region Access? }\end{array}$ & $\begin{array}{l}\text { CBT (Computer } \\
\text { Based Training) } \\
\text { Pre-Requisite to } \\
\text { Obtain Access }\end{array}$ & $\begin{array}{l}\text { Functional } \\
\text { Business Owner } \\
\text { POC: }\end{array}$ & $\begin{array}{l}\text { Approval Level } \\
\text { Designation } \\
\text { Required for } \\
\text { Profile? }\end{array}$ \\
\hline Office Support & $\begin{array}{l}\text { Clerical and } \\
\text { office } \\
\text { administrative } \\
\text { personnel } \\
\text { responsible for } \\
\text { entering orders } \\
\text { basic cataloged } \\
\text { office supplies in } \\
\text { support of the } \\
\text { line organization }\end{array}$ & $\begin{array}{ll}\text { - } & \text { Master } \\
& \text { catalog } \\
\text { Material } \\
\text { request } \\
\text { - Vendor } \\
\text { Search } \\
\text { Electronic } \\
\text { approval } \\
\text { routing } \\
\text { In-line order } \\
\text { status } \\
\text { View MSDS } \\
\text { - Purchase } \\
\text { requisitions }\end{array}$ & $\begin{array}{l}\text { GEN-001 } \\
\text { Course No. } \\
\text { 085000 } \\
\text { PassPort } \\
\text { General Supplies } \\
\text { Workshop for } \\
\text { Office Support } \\
\text { and PHMC } \\
\text { Employees }\end{array}$ & No & $\begin{array}{l}\text { Systems Basics } \\
\text { Portal/97 CBT }\end{array}$ & $\begin{array}{l}\text { Shari Bultena } \\
\text { (Inventory) } \\
\text { Kim Schultz } \\
\text { (Purchasing) } \\
\text { Mike Stephenson } \\
\text { (MSDS) }\end{array}$ & $\begin{array}{l}\text { Auto-Approve } \\
\text { Material } \\
\text { Requests }\end{array}$ \\
\hline
\end{tabular}


DOC ITEM: Security Administration Plan HNF- 2713, Rev.0

JATE: $09 / 15 / 98$

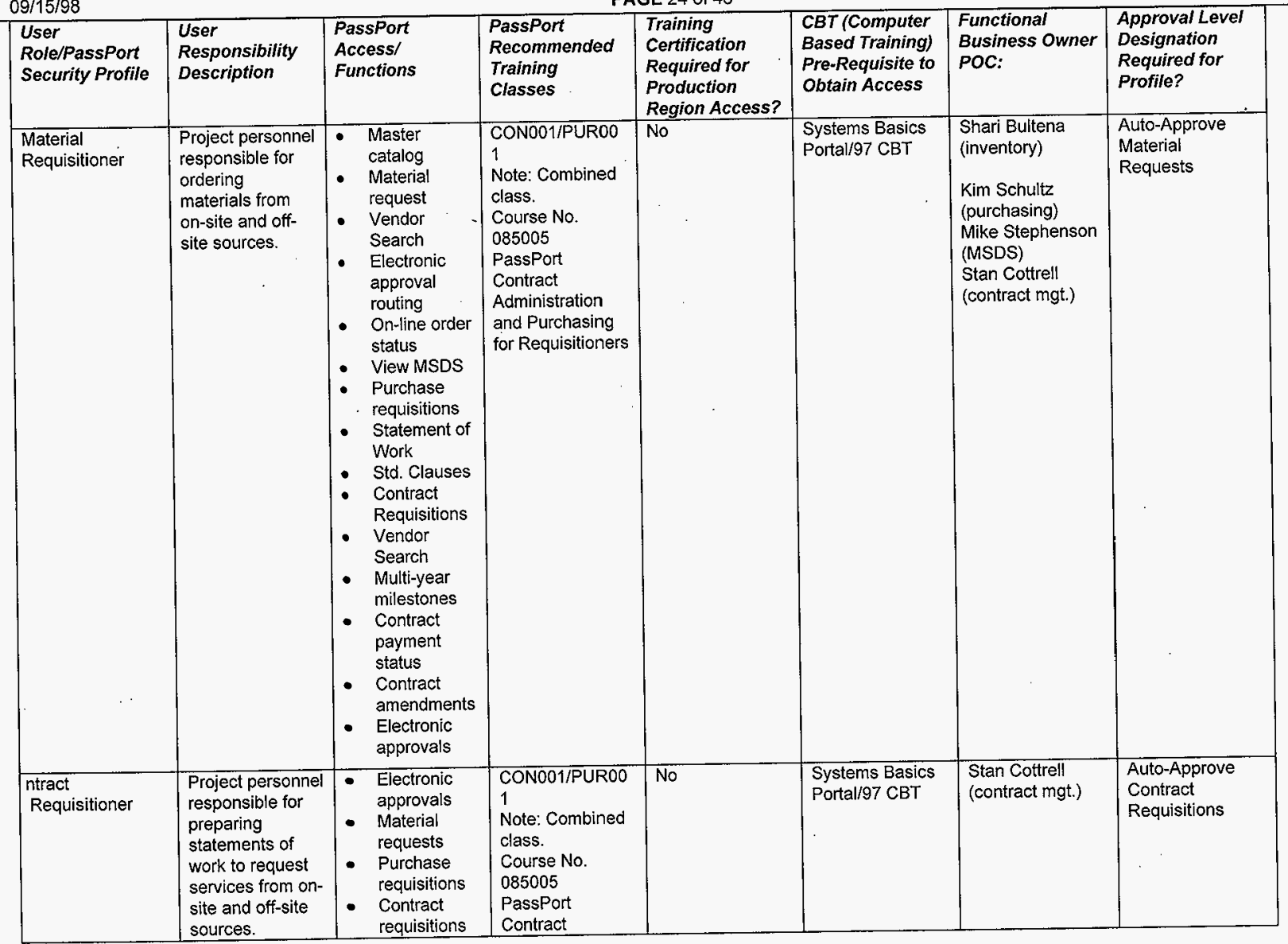


PAGE 25 of 46

\begin{tabular}{|c|c|c|c|c|c|c|c|}
\hline $\begin{array}{l}\text { User } \\
\text { Role/PassPort } \\
\text { Security Profile }\end{array}$ & $\begin{array}{l}\text { User } \\
\text { Responsibility } \\
\text { Description }\end{array}$ & $\begin{array}{l}\text { PassPort } \\
\text { Access/ } \\
\text { Functions }\end{array}$ & $\begin{array}{l}\text { PassPort } \\
\text { Recommended } \\
\text { Training } \\
\text { Classes }\end{array}$ & $\begin{array}{l}\text { Training } \\
\text { Certification } \\
\text { Required for } \\
\text { Production } \\
\text { Region Access? }\end{array}$ & $\begin{array}{l}\text { CBT (Computer } \\
\text { Based Training) } \\
\text { Pre-Requisite to } \\
\text { Obtain Access }\end{array}$ & $\begin{array}{l}\text { Functional } \\
\text { Business Owner } \\
\text { POC: }\end{array}$ & $\begin{array}{l}\text { Approval Level } \\
\text { Designation } \\
\text { Required for } \\
\text { Profile? }\end{array}$ \\
\hline . & . & $\begin{array}{l}\text { - Purchase } \\
\text { orders } \\
\text { Contract } \\
\text { amendments } \\
\text { - Payment } \\
\text { authorization } \\
\text { s } \\
\end{array}$ & $\begin{array}{l}\text { Administration } \\
\text { and Purchasing } \\
\text { for Requisitioners }\end{array}$ & & & & . \\
\hline $\begin{array}{l}\text { Requisition } \\
\text { Reviewers }\end{array}$ & $\begin{array}{l}\text { PHMC } \\
\text { managers, who } \\
\text { have signature } \\
\text { authority to } \\
\text { approve } \\
\text { requisitions, } \\
\text { authorize sole } \\
\text { sources; review } \\
\text { open workloads, } \\
\text { and track cost } \\
\text { expenditures. }\end{array}$ & $\begin{array}{ll}\text { - } & \text { Purchase } \\
\text { requisitions } \\
\text { Request for } \\
\text { Proposals } \\
\text { Vendor } \\
\text { Search } \\
\text { - Award } \\
\text { purchase } \\
\text { order } \\
\text { Expedite } \\
\text { P.O. } \\
\text { P.O. } \\
\text { Revisions } \\
\text { Payment } \\
\text { status } \\
\text { Purchasing } \\
\text { analysis } \\
\text { reports }\end{array}$ & $\begin{array}{l}\text { CON002/PUR00 } \\
2 \\
\text { Note: Combined } \\
\text { Class. } \\
\text { Course No. } \\
085010 \\
\text { PassPort } \\
\text { Contract } \\
\text { Administration } \\
\text { and Purchasing } \\
\text { Workshop for } \\
\text { Approving and } \\
\text { Reviewing } \\
\text { Management }\end{array}$ & No & $\begin{array}{l}\text { System Basics } \\
\text { Portal/97 }\end{array}$ & $\begin{array}{l}\text { Chris Hopkins } \\
\text { (supply chain } \\
\text { mgt.) }\end{array}$ & $\begin{array}{l}\text { Yes } \\
\text { Dollar signature } \\
\text { level }\end{array}$ \\
\hline Buyers & $\begin{array}{l}\text { Manages the } \\
\text { work of } \\
\text { Procurement } \\
\text { personnel who } \\
\text { prepare and } \\
\text { issue purchase } \\
\text { orders for } \\
\text { material items. }\end{array}$ & $\begin{array}{l}\text { Open buyer } \\
\text { requisition } \\
\text { backlog } \\
\text { Purchase } \\
\text { requisitions } \\
\text { Request for } \\
\text { Proposals } \\
\text { Vendor } \\
\text { Search } \\
\text { Award } \\
\text { purchase } \\
\text { order } \\
\text { Expedite }\end{array}$ & $\begin{array}{l}\text { PUR003 } \\
\text { Course No. } \\
\text { 085020 } \\
\text { PassPort } \\
\text { Purchasing } \\
\text { Workshop for } \\
\text { Buyers }\end{array}$ & $\begin{array}{l}\text { Yes } \\
\text { Challenge } \\
\text { Course by } \\
\text { Demonstrating } \\
\text { ability to navigate } \\
\text { in PassPort and } \\
\text { perform basic } \\
\text { purchasing } \\
\text { module functions. }\end{array}$ & $\begin{array}{l}\text { Yes if challenging } \\
\text { course must } \\
\text { complete System } \\
\text { Basics Portal/97 } \\
\text { CBT }\end{array}$ & $\begin{array}{l}\text { Kim Schultz } \\
\text { (purchasing) } \\
\text { Shari Bultena } \\
\text { (inventory mgt.) }\end{array}$ & $\begin{array}{l}\text { Buyer } \\
\text { procurement } \\
\text { authority } \\
\text { approval level } \\
\text { required for } \\
\text { purchase } \\
\text { requisitions and } \\
\text { P.O. revisions. }\end{array}$ \\
\hline
\end{tabular}


JOC ITEM: Security Administration Plan HNF- 2713, Rev.0 JATE: $09 / 15 / 98$

\begin{tabular}{|c|c|c|c|c|c|c|c|}
\hline $\begin{array}{l}\text { User } \\
\text { Role/PassPort } \\
\text { Security Profile }\end{array}$ & $\begin{array}{l}\text { User } \\
\text { Responsibility } \\
\text { Description }\end{array}$ & $\begin{array}{l}\text { PassPort } \\
\text { Access/ } \\
\text { Functions }\end{array}$ & $\begin{array}{l}\text { PassPort } \\
\text { Recommended } \\
\text { Training } \\
\text { Classes }\end{array}$ & \begin{tabular}{|l|} 
Training \\
Certification \\
Required for \\
Production \\
Region Access? \\
\end{tabular} & $\begin{array}{l}\text { CBT (Computer } \\
\text { Based Training) } \\
\text { Pre-Requisite to } \\
\text { Obtain Access }\end{array}$ & $\begin{array}{l}\text { Functional } \\
\text { Business Owner } \\
\text { POC: }\end{array}$ & $\begin{array}{l}\text { Approval Level } \\
\text { Designation } \\
\text { Required for } \\
\text { Profile? }\end{array}$ \\
\hline . & & \begin{tabular}{|l} 
P.O. \\
P.O. \\
Revisions \\
Payment \\
status \\
- Purchasing \\
analysis \\
reports \\
Electronic \\
approvals \\
Vendor \\
performance \\
Payment \\
status \\
Reassign \\
purchase \\
requisitions \\
Buyer \\
performance \\
analysis \\
\end{tabular} & . & & & . & \\
\hline Buyer Manager & $\begin{array}{l}\text { Procurement } \\
\text { personnel who } \\
\text { prepares and } \\
\text { issues purchase } \\
\text { orders for } \\
\text { material items. }\end{array}$ & 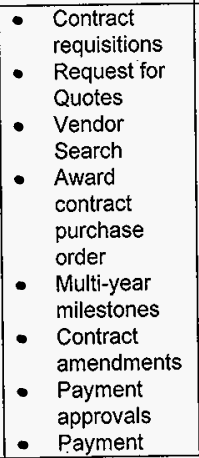 & $\begin{array}{l}\text { PUR003 } \\
\text { Course No. } \\
085020 \\
\text { PassPort } \\
\text { Purchasing } \\
\text { Workshop for } \\
\text { Buyers }\end{array}$ & $\begin{array}{l}\text { Yes; } \\
\text { Challenge } \\
\text { Course by } \\
\text { Demonstrating } \\
\text { ability to navigate } \\
\text { in PassPort and } \\
\text { perform buyer } \\
\text { backlog review } \\
\text { and assignment, } \\
\text { and basic } \\
\text { contract } \\
\text { administration } \\
\text { module functions. }\end{array}$ & $\begin{array}{l}\text { Yes if challenging } \\
\text { course must } \\
\text { complete System } \\
\text { Basics Portal/97 } \\
\text { CBT }\end{array}$ & $\begin{array}{l}\text { Kim Schultz } \\
\text { (purchasing) } \\
\text { Shari Bultena } \\
\text { (inventory mgt.) }\end{array}$ & $\begin{array}{l}\text { Buyer Manager } \\
\text { procurement } \\
\text { authority } \\
\text { approval level } \\
\text { required for } \\
\text { purchase } \\
\text { requisitions and } \\
\text { P.O. revisions. }\end{array}$ \\
\hline
\end{tabular}




\begin{tabular}{|c|c|c|c|c|c|c|c|}
\hline $\begin{array}{l}\text { User } \\
\text { Role/PassPort } \\
\text { Security Profile }\end{array}$ & $\begin{array}{l}\text { User } \\
\text { Responsibility } \\
\text { Description }\end{array}$ & $\begin{array}{l}\text { PassPort } \\
\text { Access/ } \\
\text { Functions }\end{array}$ & $\begin{array}{l}\text { PassPort } \\
\text { Recommended } \\
\text { Training } \\
\text { Classes }\end{array}$ & $\begin{array}{l}\text { Training } \\
\text { Certification } \\
\text { Required for } \\
\text { Production } \\
\text { Region Access? }\end{array}$ & $\begin{array}{l}\text { CBT (Computer } \\
\text { Based Training) } \\
\text { Pre-Requisite to } \\
\text { Obtain Access }\end{array}$ & $\begin{array}{l}\text { Functional } \\
\text { Business Owner } \\
\text { POC: }\end{array}$ & $\begin{array}{l}\text { Approval Level } \\
\text { Designation } \\
\text { Required for } \\
\text { Profile? }\end{array}$ \\
\hline & & $\begin{array}{l}\text { status } \\
\text { Contract } \\
\text { analysis } \\
\text { reports }\end{array}$ & & & . & & \\
\hline $\begin{array}{l}\text { Contract } \\
\text { Administrator }\end{array}$ & $\begin{array}{l}\text { Procurement } \\
\text { personnel who } \\
\text { prepare and } \\
\text { issue purchase } \\
\text { orders for } \\
\text { services. }\end{array}$ & $\begin{array}{l}\text { - Assign open } \\
\text { contract } \\
\text { requisition } \\
\text { buyer } \\
\text { backlog } \\
\text { Contract } \\
\text { requisitions } \\
\text { Request for } \\
\text { Quotes } \\
\text { Vendor } \\
\text { Search } \\
\text { Award } \\
\text { contract } \\
\text { purchase } \\
\text { order } \\
\text { Multi-year } \\
\text { milestones } \\
\text { Contract } \\
\text { amendments } \\
\text { Payment } \\
\text { approvals } \\
\text { Payment } \\
\text { status } \\
\text { Contract } \\
\text { analysis } \\
\text { reports } \\
\end{array}$ & $\begin{array}{l}\text { CON004 } \\
\text { Course No. } \\
085025 \\
\text { PassPort } \\
\text { Contract } \\
\text { Administration for } \\
\text { Contract } \\
\text { Administrators }\end{array}$ & $\begin{array}{l}\text { Yes } \\
\text { Challenge } \\
\text { Course by } \\
\text { Demonstrating } \\
\text { ability to navigate } \\
\text { in PassPort and } \\
\text { perform basic } \\
\text { purchasing } \\
\text { module functions. }\end{array}$ & $\begin{array}{l}\text { Yes if challenging } \\
\text { course must } \\
\text { complete System } \\
\text { Basics Portal/97 } \\
\text { CBT }\end{array}$ & $\begin{array}{l}\text { Kim Schultz } \\
\text { (Contract mgt.) } \\
\text { Bob Allen } \\
\text { (Vendors) } \\
\text { Brent Wagner } \\
\text { (accounts } \\
\text { payable) }\end{array}$ & $\begin{array}{l}\text { Contract } \\
\text { administrator } \\
\text { procurement } \\
\text { authority } \\
\text { approval level } \\
\text { required for } \\
\text { contract } \\
\text { requisitions } \\
\text { contract } \\
\text { amendments, } \\
\text { and contract } \\
\text { payments. }\end{array}$ \\
\hline $\begin{array}{l}\text { Contract } \\
\text { Administrator } \\
\text { Manager }\end{array}$ & $\begin{array}{l}\text { Manages the } \\
\text { work of } \\
\text { Procurement } \\
\text { personnel who } \\
\text { prepare, issue, } \\
\text { and administer } \\
\text { contract } \\
\text { purchase orders }\end{array}$ & $\begin{array}{l}\text { Contract } \\
\text { requisitions } \\
\text { Statements } \\
\text { of work } \\
\text { - Contract } \\
\text { amendments } \\
\text { - Payment } \\
\text { authorization }\end{array}$ & $\begin{array}{l}\text { CON004 } \\
\text { Course No. } \\
085025 \\
\text { PassPort } \\
\text { Contract } \\
\text { Administration for } \\
\text { Contract } \\
\text { Administrators }\end{array}$ & $\begin{array}{l}\text { Yes; } \\
\text { Challenge } \\
\text { Course by } \\
\text { Demonstrating } \\
\text { ability to navigate } \\
\text { in PassPort and } \\
\text { perform buyer } \\
\text { backlog review }\end{array}$ & $\begin{array}{l}\text { Yes if challenging } \\
\text { course must } \\
\text { complete System } \\
\text { Basics Portal/97 } \\
\text { CBT }\end{array}$ & $\begin{array}{l}\text { Kim Schultz } \\
\text { (contract mgt.) } \\
\text { Bob Allen } \\
\text { (Vendors) } \\
\text { Brent Wagner } \\
\text { (accounts } \\
\text { payable) }\end{array}$ & $\begin{array}{l}\text { Contract } \\
\text { administrator } \\
\text { Manager } \\
\text { procurement } \\
\text { authority } \\
\text { approval level } \\
\text { required for } \\
\text { contract }\end{array}$ \\
\hline
\end{tabular}


PAGE 28 of 46

\begin{tabular}{|c|c|c|c|c|c|c|c|}
\hline $\begin{array}{l}\text { User } \\
\text { Role/PassPort } \\
\text { Security Profile }\end{array}$ & $\begin{array}{l}\text { User } \\
\text { Responsibility } \\
\text { Description }\end{array}$ & $\begin{array}{l}\text { PassPort } \\
\text { Access/ } \\
\text { Functions }\end{array}$ & $\begin{array}{l}\text { PassPort } \\
\text { Recommended } \\
\text { Training } \\
\text { Classes }\end{array}$ & $\begin{array}{l}\text { Training } \\
\text { Certification } \\
\text { Required for } \\
\text { Production } \\
\text { Region Access? }\end{array}$ & $\begin{array}{l}\text { CBT (Computer } \\
\text { Based Training) } \\
\text { Pre-Requisite to } \\
\text { Obtain Access }\end{array}$ & $\begin{array}{l}\text { Functional } \\
\text { Business Owner } \\
\text { POC: }\end{array}$ & $\begin{array}{l}\text { Approval Level } \\
\text { Designation } \\
\text { Required for } \\
\text { Profile? }\end{array}$ \\
\hline & for services. & $\begin{array}{l}\text { - } \\
\text { Payment } \\
\text { status }\end{array}$ & & $\begin{array}{l}\text { and assignment, } \\
\text { and basic } \\
\text { contract } \\
\text { administration } \\
\text { module functions. }\end{array}$ & & . & $\begin{array}{l}\text { requisitions } \\
\text { contract } \\
\text { amendments, } \\
\text { and contract } \\
\text { payments. }\end{array}$ \\
\hline $\begin{array}{l}\text { Buyer Technical } \\
\text { Representative }\end{array}$ & $\begin{array}{l}\text { Project personnel } \\
\text { who are } \\
\text { responsible for } \\
\text { reviewing and } \\
\text { approving } \\
\text { payment } \\
\text { approvals for } \\
\text { services } \\
\text { performed on } \\
\text { contracts. }\end{array}$ & $\begin{array}{ll}\text { - } & \text { Master } \\
\text { catalog } \\
\text { Material } \\
\text { request } \\
\text { Electronic } \\
\text { approvals } \\
\text { Cycle } \\
\text { counting } \\
\text { Replenish- } \\
\text { ments } \\
\text { Standards } \\
\text { and } \\
\text { procedures } \\
\text { Purchase } \\
\text { requisitions } \\
\text { Inventory } \\
\text { mgt. analysis }\end{array}$ & $\begin{array}{l}\text { CON005/PUR00 } \\
\text { 5Note: Classes } \\
\text { combined. } \\
\text { Course No. } \\
085035 \\
\text { PassPort } \\
\text { Contract and } \\
\text { Purchasing } \\
\text { Workshop for } \\
\text { Buyer Technical } \\
\text { Reps. }\end{array}$ & No & $\begin{array}{l}\text { System Basics } \\
\text { Portal/97 CBT }\end{array}$ & $\begin{array}{l}\text { Kim Schultz } \\
\text { (contract mgt.) } \\
\text { Brent Wagner } \\
\text { (accounts } \\
\text { payable) }\end{array}$ & No \\
\hline $\begin{array}{l}\text { Inventory } \\
\text { Management } \\
\text { Specialist }\end{array}$ & $\begin{array}{l}\text { Project personnel } \\
\text { who are } \\
\text { responsible for } \\
\text { maintaing } \\
\text { adequate } \\
\text { stocking levels } \\
\text { for general } \\
\text { supplies, spare } \\
\text { parts; } \\
\text { convenience } \\
\text { storage, special } \\
\text { tools, and } \\
\text { equipment }\end{array}$ & $\begin{array}{ll} & \text { Master } \\
\text { catalog } \\
\text { Material } \\
\text { request } \\
\text { Central } \\
\text { receiving log } \\
\text { Warehouse } \\
\text { locations } \\
\text { Material } \\
\text { reservations } \\
\text { Vendor } \\
\text { search } \\
\text { OSD\&D }\end{array}$ & $\begin{array}{l}\text { INV-001 } \\
\text { Course No. } \\
085040 \\
\text { PassPort } \\
\text { Inventory Mgt. for } \\
\text { Inventory Mgt. } \\
\text { Specialists. }\end{array}$ & Yes & $\begin{array}{l}\text { Systems Basics } \\
\text { Portal/97 CBT }\end{array}$ & $\begin{array}{l}\text { Shari Bultena } \\
\text { (inventory mgt.) } \\
\text { Kim Schultz } \\
\text { (purchasing) } \\
\text { Bob Allen } \\
\text { (vendors) }\end{array}$ & $\begin{array}{l}\text { Approve new } \\
\text { Master Catalog } \\
\text { ID's } \\
\text { Cycle Count } \\
\text { Variance } \\
\text { Approval }\end{array}$ \\
\hline
\end{tabular}


OC ITEM: Security Administration Plan HNF- 2713, Rev.0 OATE: $09 / 15 / 98$

\begin{tabular}{|c|c|c|c|c|c|c|c|}
\hline $\begin{array}{l}\text { User } \\
\text { Role/PassPort } \\
\text { Security Profile }\end{array}$ & $\begin{array}{l}\text { User } \\
\text { Responsibility } \\
\text { Description }\end{array}$ & $\begin{array}{l}\text { PassPort } \\
\text { Access/ } \\
\text { Functions }\end{array}$ & $\begin{array}{l}\text { PassPort } \\
\text { Recommended } \\
\text { Training } \\
\text { Classes }\end{array}$ & \begin{tabular}{|l|} 
Training \\
Certification \\
Required for \\
Production \\
Region Access? \\
\end{tabular} & $\begin{array}{l}\text { CBT (Computer } \\
\text { Based Training) } \\
\text { Pre-Requisite to } \\
\text { Obtain Access }\end{array}$ & $\begin{array}{l}\text { Functional } \\
\text { Business Owner } \\
\text { POC: }\end{array}$ & $\begin{array}{l}\text { Approval Level } \\
\text { Designation } \\
\text { Required for } \\
\text { Profile? }\end{array}$ \\
\hline & $\begin{array}{l}\text { financial and } \\
\text { non-financial } \\
\text { controlled } \\
\text { inventories. }\end{array}$ & $\begin{array}{ll}\text { QC } \\
\text { inspection } \\
\text { Warehouse } \\
\text { distribution } \\
\text { - Shipping } \\
\end{array}$ & & & & & \\
\hline $\begin{array}{l}\text { Warehouse } \\
\text { Storekeeper }\end{array}$ & $\begin{array}{l}\text { Project personnel } \\
\text { who are } \\
\text { responsible for } \\
\text { performing } \\
\text { warehouse work } \\
\text { associated with } \\
\text { receiving, } \\
\text { disbursing, } \\
\text { counting, and } \\
\text { shipping general } \\
\text { supplies, spare } \\
\text { parts, } \\
\text { convenience } \\
\text { storage, special } \\
\text { tools, and } \\
\text { equipment } \\
\text { stocked in } \\
\text { Materials Mgt. } \\
\text { controlled } \\
\text { warehouses. } \\
\end{array}$ & 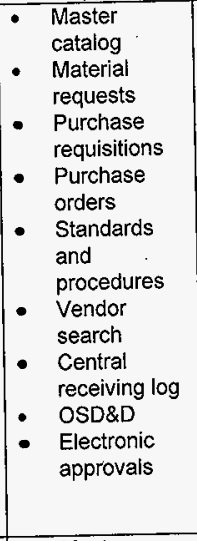 & $\begin{array}{l}\text { INV-002 } \\
\text { Course No. } \\
085045 \\
\text { PassPort } \\
\text { Inventory } \\
\text { Management for } \\
\text { Warehouse } \\
\text { Personnel }\end{array}$ & Yes & $\begin{array}{l}\text { System Basics } \\
\text { Portal/97 CBT }\end{array}$ & $\begin{array}{l}\text { Shari Bultena } \\
\text { (inventory mgt.) } \\
\text { Kim Schultz } \\
\text { (purchasing) } \\
\text { Bob Allen } \\
\text { (vendors) }\end{array}$ & $\begin{array}{l}\text { Auto approve } \\
\text { material requests }\end{array}$ \\
\hline QC Inspection & $\begin{array}{l}\text { Project personnel } \\
\text { that are } \\
\text { responsible for } \\
\text { quality control } \\
\text { receiving } \\
\text { inspection for } \\
\text { material items } \\
\text { received at the } \\
2355 \text { Stevens } \\
\text { central receiving } \\
\text { warehouse. }\end{array}$ & 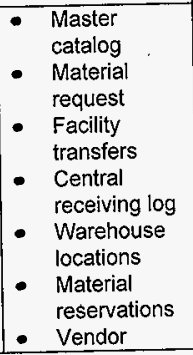 & $\begin{array}{l}\text { INV-003 } \\
\text { Course No. } \\
085050 \\
\text { PassPort } \\
\text { Inventory Mgt. for } \\
\text { Quality Control } \\
\text { Inspectors }\end{array}$ & Yes & $\begin{array}{l}\text { System Basics } \\
\text { Portal/97 CBT }\end{array}$ & $\begin{array}{l}\text { Shari Bultena } \\
\text { (inventory mgt.) } \\
\text { Kim Schultz } \\
\text { (purchasing) } \\
\text { Bob Allen } \\
\text { (vendors) } \\
\text { Mike Taylor } \\
\text { (standards and } \\
\text { procedures) }\end{array}$ & No \\
\hline
\end{tabular}


PAGE 30 of 46

\begin{tabular}{|c|c|c|c|c|c|c|c|}
\hline $\begin{array}{l}\text { User } \\
\text { Role/PassPort } \\
\text { Security Profile }\end{array}$ & $\begin{array}{l}\text { User } \\
\text { Responsibility } \\
\text { Description }\end{array}$ & $\begin{array}{l}\text { PassPort } \\
\text { Access/ } \\
\text { Functions }\end{array}$ & $\begin{array}{l}\text { PassPort } \\
\text { Recommended } \\
\text { Training } \\
\text { Classes }\end{array}$ & $\begin{array}{l}\text { Training } \\
\text { Certification } \\
\text { Required for } \\
\text { Production } \\
\text { Region Access? }\end{array}$ & $\begin{array}{l}\text { CBT (Computer } \\
\text { Based Training) } \\
\text { Pre-Requisite to } \\
\text { Obtain Access }\end{array}$ & $\begin{array}{l}\text { Functional } \\
\text { Business Owner } \\
\text { POC: }\end{array}$ & $\begin{array}{l}\text { Approval Level } \\
\text { Designation } \\
\text { Required for } \\
\text { Profile? }\end{array}$ \\
\hline & & $\begin{array}{ll} & \text { search } \\
\text { - OSD\&D } \\
\text { Warehouse } \\
\text { distribution } \\
\text { - Shipping } \\
\text { - Cycle } \\
\text { counting } \\
\text { - Tier II } \\
\text { reporting } \\
\text { MSDS }\end{array}$ & & & & & \\
\hline $\begin{array}{l}\text { Chemical } \\
\text { Inventory } \\
\text { Specialist }\end{array}$ & $\begin{array}{l}\text { Project personnel } \\
\text { responsible for } \\
\text { the receipt, } \\
\text { warehousing, } \\
\text { disbursement, } \\
\text { disposal, and } \\
\text { physical } \\
\text { inventorying of } \\
\text { chemical } \\
\text { inventories within } \\
\text { Project facilities. }\end{array}$ & $\begin{array}{ll}\text { - } & \text { Schedule } \\
\text { cycle counts } \\
\text { - Master } \\
\text { catalog } \\
\text { - Material } \\
\text { request } \\
\text { - Central } \\
\text { receiving log } \\
\text { - Warehouse } \\
\text { locations } \\
\text { - Material } \\
\text { reservations } \\
\text { - Vendor } \\
\text { search } \\
\text { - OSD\&D } \\
\text { - QC } \\
\text { inspection } \\
\text { - Warehouse } \\
\text { distribution } \\
\text { - Shipping }\end{array}$ & $\begin{array}{l}\text { INV-004 } \\
\text { Course No. } \\
085055 \\
\text { PassPort } \\
\text { Inventory } \\
\text { Management for } \\
\text { Chemical } \\
\text { Inventory Mgt. } \\
\text { Specialists }\end{array}$ & Yes & $\begin{array}{l}\text { System Basics } \\
\text { Portal/97 CBT }\end{array}$ & $\begin{array}{l}\text { Mike Stephenson } \\
\text { (Chemical } \\
\text { inventory mgt. } \\
\text { and MSDS) } \\
\text { Shari Bultena } \\
\text { (master catalog) } \\
\text { Bob Allen } \\
\text { (vendors) } \\
\text { Kim Schultz } \\
\text { (purchasing) }\end{array}$ & Nọ \\
\hline $\begin{array}{l}\text { Warehouse } \\
\text { Manager }\end{array}$ & $\begin{array}{l}\text { Manager of } \\
\text { Project personnel } \\
\text { who are } \\
\text { responsible for } \\
\text { performing } \\
\text { warehouse work } \\
\text { associated with } \\
\text { receiving. }\end{array}$ & $\begin{array}{ll}\text { - } & \text { Invoice } \\
& \text { search } \\
\text { - } & \text { Payment } \\
\text { status } \\
\text { - Print checks } \\
\text { - Reconcile } \\
\text { bank } \\
\text { accounts }\end{array}$ & $\begin{array}{l}\text { INV-002 } \\
\text { Course No. } \\
085045 \\
\text { PassPort } \\
\text { Inventory } \\
\text { Management for } \\
\text { Warehouse } \\
\text { Personnel }\end{array}$ & Yes & $\begin{array}{l}\text { System Basics } \\
\text { Portal/97 CBT }\end{array}$ & $\begin{array}{l}\text { Shari Bultena } \\
\text { (inventory mgt.) } \\
\text { Kim Schultz } \\
\text { (purchasing) } \\
\text { Bob Allen } \\
\text { (vendors) }\end{array}$ & $\begin{array}{l}\text { Auto Approve } \\
\text { material requests }\end{array}$ \\
\hline
\end{tabular}


DOC ITEM: Security Administration Plan HNF- 2713, Rev.0

DATE: $09 / 15 / 98$

PAGE 31 of 46

\begin{tabular}{|c|c|c|c|c|c|c|c|}
\hline $\begin{array}{l}\text { User } \\
\text { Role/PassPort } \\
\text { Security Profile }\end{array}$ & $\begin{array}{l}\text { User } \\
\text { Responsibility } \\
\text { Description }\end{array}$ & $\begin{array}{l}\text { PassPort } \\
\text { Access/ } \\
\text { Functions }\end{array}$ & $\begin{array}{l}\text { PassPort } \\
\text { Recommended } \\
\text { Training } \\
\text { Classes }\end{array}$ & $\begin{array}{l}\text { Training } \\
\text { Certification } \\
\text { Required for } \\
\text { Production } \\
\text { Region Access? }\end{array}$ & $\begin{array}{l}\text { CBT (Computer } \\
\text { Based Training) } \\
\text { Pre-Requisite to } \\
\text { Obtain Access }\end{array}$ & $\begin{array}{l}\text { Functional } \\
\text { Business Owner } \\
\text { POC: }\end{array}$ & $\begin{array}{l}\text { Approval Level } \\
\text { Designation } \\
\text { Required for } \\
\text { Profile? }\end{array}$ \\
\hline . & $\begin{array}{l}\text { disbursing, } \\
\text { counting, and } \\
\text { shipping general } \\
\text { supplies, spare } \\
\text { parts, } \\
\text { convenience } \\
\text { storage, special } \\
\text { tools, and } \\
\text { equipment } \\
\text { stocked in } \\
\text { Materials Mgt. } \\
\text { controlled } \\
\text { warehouses. }\end{array}$ & $\begin{array}{l}\text { - On-demand } \\
\text { payments } \\
\text { Approve } \\
\text { checks } \\
\text { EFT } \\
\text { transmission } \\
\text { verifications } \\
\text { Cash wires } \\
\text { - Check } \\
\text { signing } \\
\end{array}$ & & & & & \\
\hline Treasury & $\begin{array}{l}\text { Accounting staff } \\
\text { responsible for } \\
\text { approving and } \\
\text { printing checks } \\
\text { for payments to } \\
\text { satisfy } \\
\text { outstanding } \\
\text { accounts } \\
\text { payable. }\end{array}$ & 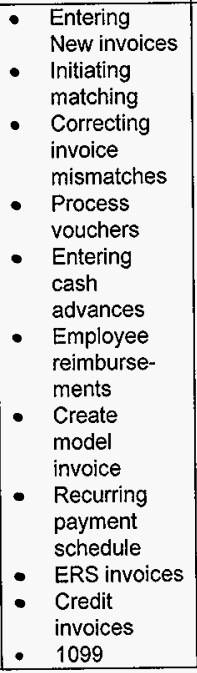 & $\begin{array}{l}\text { AP-001 PassPort } \\
\text { Accounts } \\
\text { Payable }\end{array}$ & Yes & $\begin{array}{l}\text { Systems Basics } \\
\text { Portal/97 CBT }\end{array}$ & $\begin{array}{l}\text { Brent Wagner } \\
\text { (accounts } \\
\text { payable) } \\
\text { Bob Allen } \\
\text { (vendors) }\end{array}$ & No \\
\hline
\end{tabular}




\begin{tabular}{|c|c|c|c|c|c|c|c|}
\hline $\begin{array}{l}\text { User } \\
\text { Role/PassPort } \\
\text { Security Profile }\end{array}$ & $\begin{array}{l}\text { User } \\
\text { Responsibility } \\
\text { Description }\end{array}$ & $\begin{array}{l}\text { PassPort } \\
\text { Access/ } \\
\text { Functions }\end{array}$ & $\begin{array}{l}\text { PassPort } \\
\text { Recommended } \\
\text { Training } \\
\text { Classes }\end{array}$ & $\begin{array}{l}\text { Training } \\
\text { Certification } \\
\text { Required for } \\
\text { Production } \\
\text { Region Access? }\end{array}$ & $\begin{array}{l}\text { CBT (Computer } \\
\text { Based Training) } \\
\text { Pre-Requisite to } \\
\text { Obtain Access }\end{array}$ & $\begin{array}{l}\text { Functional } \\
\text { Business Owner } \\
\text { POC: }\end{array}$ & $\begin{array}{l}\text { Approval Level } \\
\text { Designation } \\
\text { Required for } \\
\text { Profile? }\end{array}$ \\
\hline & & processing & & & & & \\
\hline $\begin{array}{l}\text { AP Invoice } \\
\text { Auditor }\end{array}$ & $\begin{array}{l}\text { Accounting } \\
\text { personnel } \\
\text { responsible for } \\
\text { entering invoices, } \\
\text { generating } \\
\text { verifications of } \\
\text { service for } \\
\text { payment } \\
\text { approvals, } \\
\text { reconciling } \\
\text { invoices and } \\
\text { payments, and } \\
\text { entering vendor } \\
\text { remit to } \\
\text { information. }\end{array}$ & $\begin{array}{ll}\text { - } & \text { Initiating } \\
\text { matching } \\
\text { - } & \text { Recuring } \\
\text { payment } \\
\text { schedule } \\
\text { - } \\
\text { ERS invoices } \\
\text { approvals } \\
\text { - Credit } \\
\text { invoice } \\
\text { approvals } \\
\text { - Payment } \\
\text { approval } \\
\text { 1099 } \\
\text { processing }\end{array}$ & $\begin{array}{l}\text { AP-001 } \\
\text { PassPort } \\
\text { Accounts } \\
\text { Payable }\end{array}$ & Yes & $\begin{array}{l}\text { System Basics } \\
\text { Portal/97 CBT }\end{array}$ & $\begin{array}{l}\text { Brent Wagner } \\
\text { (accounts } \\
\text { payable) } \\
\text { Kim S.chultz } \\
\text { (purchasing \& } \\
\text { contract mgt.) } \\
\text {.Bob Allen } \\
\text { (vendors) }\end{array}$ & No \\
\hline $\begin{array}{l}\text { AP Payment } \\
\text { Approver }\end{array}$ & $\begin{array}{l}\text { Accounting } \\
\text { personnel } \\
\text { responsible for } \\
\text { approving } \\
\text { payments for the } \\
\text { purpose of } \\
\text { authorizing } \\
\text { payment of } \\
\text { outstanding } \\
\text { company } \\
\text { payables. }\end{array}$ & $\begin{array}{ll} & \text { Create new } \\
\text { vendor } \\
\text { Update } \\
\text { vendor } \\
\text { information } \\
\text { - Update } \\
\text { vendor remit } \\
\text { to } \\
\text { information } \\
\text { Vendor } \\
\text { status } \\
\end{array}$ & $\begin{array}{l}\text { AP-001 } \\
\text { PassPort } \\
\text { Accounts } \\
\text { Payable }\end{array}$ & Yes & $\begin{array}{l}\text { Systems Basics } \\
\text { Portal/97 CBT }\end{array}$ & $\begin{array}{l}\text { Brent Wagner } \\
\text { (accounts } \\
\text { payable) } \\
\text { Kim Schultz } \\
\text { (purchasing \& } \\
\text { contract mgt.) } \\
\text { Bob Allen } \\
\text { (vendors) }\end{array}$ & $\begin{array}{l}\text { Yes } \\
\text { Dollar signature } \\
\text { level }\end{array}$ \\
\hline AP Misc & $\begin{array}{l}\text { Accounting } \\
\text { personnel } \\
\text { responsible for } \\
\text { various AP tasks }\end{array}$ & $\begin{array}{l}\text { Deleting } \\
\text { invoices } \\
\text { administering } \\
\text { recurring } \\
\text { invoices \& } \\
\text { recurring } \\
\text { payment } \\
\text { schedules } \\
\text { entering }\end{array}$ & $\begin{array}{l}\text { PASSPORT } \\
\text { Accounts } \\
\text { Payable }\end{array}$ & Yes & $\begin{array}{l}\text { Systems Basics } \\
\text { Portal/97 CBT }\end{array}$ & $\begin{array}{l}\text { Brent Wagner } \\
\text { (accounts } \\
\text { payable) } \\
\text { Kim Schultz } \\
\text { (purchasing \& } \\
\text { contract mgt.) } \\
\text { Bob Allen } \\
\text { (vendors) }\end{array}$ & $\begin{array}{l}\text { Yes } \\
\text { Dollar signature } \\
\text { level }\end{array}$ \\
\hline
\end{tabular}


JOC ITEM: Security Administration Plan HNF- 2713, Rev.0 JATE: $09 / 15 / 98$

PAGE 33 of 46

\begin{tabular}{|c|c|c|c|c|c|c|c|}
\hline $\begin{array}{l}\text { User } \\
\text { Role/PassPort } \\
\text { Security Profile }\end{array}$ & $\begin{array}{l}\text { User } \\
\text { Responsibility } \\
\text { Description }\end{array}$ & $\begin{array}{l}\text { PassPort } \\
\text { Access/ } \\
\text { Functions }\end{array}$ & $\begin{array}{l}\text { PassPort } \\
\text { Recommended } \\
\text { Training } \\
\text { Classes }\end{array}$ & $\begin{array}{l}\text { Training } \\
\text { Certification } \\
\text { Required for } \\
\text { Production } \\
\text { Region Access? }\end{array}$ & $\begin{array}{l}\text { CBT (Computer } \\
\text { Based Training) } \\
\text { Pre-Requisite to } \\
\text { Obtain Access }\end{array}$ & $\begin{array}{l}\text { Functional } \\
\text { Business Owner } \\
\text { POC: }\end{array}$ & $\begin{array}{l}\text { Approval Level } \\
\text { Designation } \\
\text { Required for } \\
\text { Profile? }\end{array}$ \\
\hline & & $\begin{array}{l}\text { cash receipts } \\
\text { performing } \\
\text { contract \& } \\
\text { PO invoice } \\
\text { overrides } \\
\end{array}$ & & & & & \\
\hline AP EDI & $\begin{array}{l}\text { Accounting } \\
\text { personnel } \\
\text { responsible for } \\
\text { administering } \\
\text { EDI freight bills }\end{array}$ & $\begin{array}{l}\text { manage all } \\
\text { EDI } \\
\text { transactions }\end{array}$ & $\begin{array}{l}\text { PASSPORT } \\
\text { Accounts } \\
\text { Payable }\end{array}$ & Yes & $\begin{array}{l}\text { Systems Basics } \\
\text { Portal/97 CBT }\end{array}$ & $\begin{array}{l}\text { Brent Wagner } \\
\text { (accounts } \\
\text { payable) } \\
\text { Kim Schultz } \\
\text { (purchasing \& } \\
\text { contract mgt.) } \\
\text { Bob Allen } \\
\text { (vendors) } \\
\end{array}$ & $\begin{array}{l}\text { Yes } \\
\text { Dollar signature } \\
\text { level }\end{array}$ \\
\hline AP Checks & $\begin{array}{l}\text { Accounting } \\
\text { personnel } \\
\text { responsible for } \\
\text { running check } \\
\text { processing }\end{array}$ & $\begin{array}{l}\text { execute } \\
\text { check batch } \\
\text { for prelim } \\
\text { payment } \\
\text { register } \\
\text { process } \\
\text { immediate } \\
\text { payments } \\
\text { cancel } \\
\text { checks } \\
\end{array}$ & $\begin{array}{l}\text { PASSPORT } \\
\text { Accounts } \\
\text { Payable }\end{array}$ & Yes & $\begin{array}{l}\text { Systems Basics } \\
\text { Portal/97 CBT }\end{array}$ & $\begin{array}{l}\text { Brent Wagner } \\
\text { (accounts } \\
\text { payable) } \\
\text { Kim Schultz } \\
\text { (purchasing \& } \\
\text { contract mgt.) } \\
\text { Bob Allen } \\
\text { (vendors) }\end{array}$ & $\begin{array}{l}\text { Yes } \\
\text { Dollar signature } \\
\text { level }\end{array}$ \\
\hline AP 1099 & $\begin{array}{l}\text { Accounting } \\
\text { personnel } \\
\text { responsible for } \\
\text { administering } \\
1099 \text { reporting }\end{array}$ & 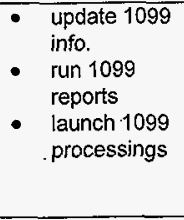 & $\begin{array}{l}\text { PASSPORT } \\
\text { Accounts } \\
\text { Payable }\end{array}$ & Yes & $\begin{array}{l}\text { Systems Basics } \\
\text { Portal/97 CBT }\end{array}$ & $\begin{array}{l}\text { Brent Wagner } \\
\text { (accounts } \\
\text { payable) } \\
\text { Kim Schultz } \\
\text { (purchasing \& } \\
\text { contract mgt.) } \\
\text { Bob Allen } \\
\text { (vendors) } \\
\end{array}$ & No \\
\hline Vendor Input & $\begin{array}{l}\text { Purchasing and } \\
\text { Accounts } \\
\text { Payable } \\
\text { personnel } \\
\text { responsible for } \\
\text { entering initial } \\
\text { vendor }\end{array}$ & $\begin{array}{l}\text { enter } \\
\text { vendors in } \\
\text { Passport } \\
\text { only }\end{array}$ & $\begin{array}{l}\text { PUR003 } \\
\text { Course No. } \\
085020 \\
\text { PassPort } \\
\text { Purchasing } \\
\text { Workshop for } \\
\text { Buyers } \\
\end{array}$ & $\begin{array}{l}\text { PUR-003 } \\
\text { PassPort } \\
\text { Purchasing } \\
\text { Workshop for } \\
\text { Buyers }\end{array}$ & $\begin{array}{l}\text { Systems Basics } \\
\text { Portal/97 CBT }\end{array}$ & $\begin{array}{l}\text { Kim Schultz } \\
\text { (purchasing \& } \\
\text { contract mgt.) } \\
\text { Brent Wagner } \\
\text { (accounts } \\
\text { payable) } \\
\text { Bob Allen } \\
\end{array}$ & No \\
\hline
\end{tabular}


OOC ITEM: Security Administration Plan HNF- 2713, Rev.0 JATE: 09/15/98

\begin{tabular}{|c|c|c|c|c|c|c|c|}
\hline $\begin{array}{l}\text { User } \\
\text { Role/PassPort } \\
\text { Security Profile }\end{array}$ & $\begin{array}{l}\text { User } \\
\text { Responsibility } \\
\text { Description }\end{array}$ & $\begin{array}{l}\text { PassPort } \\
\text { Access/ } \\
\text { Functions }\end{array}$ & $\begin{array}{l}\text { PassPort } \\
\text { Recommended } \\
\text { Training } \\
\text { Classes }\end{array}$ & $\begin{array}{l}\text { Training } \\
\text { Certification } \\
\text { Required for } \\
\text { Production } \\
\text { Region Access? }\end{array}$ & $\begin{array}{l}\text { CBT (Computer } \\
\text { Based Training) } \\
\text { Pre-Requisite to } \\
\text { Obtain Access }\end{array}$ & $\begin{array}{l}\text { Functional } \\
\text { Business Owner } \\
\text { POC: }\end{array}$ & $\begin{array}{l}\text { Approval Level } \\
\text { Designation } \\
\text { Required for } \\
\text { Profile? }\end{array}$ \\
\hline & $\begin{array}{l}\text { information in } \\
\text { PassPort. }\end{array}$ & & & & & (vendors) & \\
\hline $\begin{array}{l}\text { Vendor } \\
\text { Administrator }\end{array}$ & $\begin{array}{l}\text { Purchasing and } \\
\text { Accounts } \\
\text { Payable } \\
\text { personnel } \\
\text { responsible for } \\
\text { maintaining } \\
\text { vendor } \\
\text { information in } \\
\text { PassPort. }\end{array}$ & 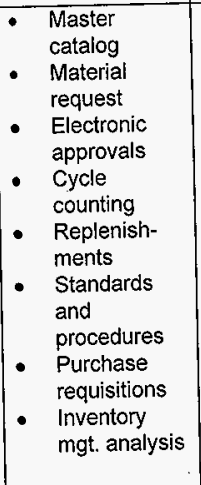 & $\begin{array}{l}\text { PUR003 } \\
\text { Course No. } \\
085020 \\
\text { PassPort } \\
\text { Purchasing } \\
\text { Workshop for } \\
\text { Buyers }\end{array}$ & $\begin{array}{l}\text { PUR-003 } \\
\text { PassPort } \\
\text { Purchasing } \\
\text { Workshop for } \\
\text { Buyers }\end{array}$ & $\begin{array}{l}\text { Systems Basics } \\
\text { Portal/97 CBT }\end{array}$ & $\begin{array}{l}\text { Kim Schultz } \\
\text { (purchasing \& } \\
\text { contract mgt.) } \\
\text { Brent Wagner } \\
\text { (accounts } \\
\text { payable) } \\
\text { Bob Allen } \\
\text { (vendors) }\end{array}$ & No \\
\hline $\begin{array}{l}\text { Inventory } \\
\text { Manager }\end{array}$ & $\begin{array}{l}\text { Manager of the } \\
\text { Project personnel } \\
\text { who are } \\
\text { responsible for } \\
\text { maintaining } \\
\text { adequate } \\
\text { stocking levels } \\
\text { for general } \\
\text { supplies, spare } \\
\text { parts, } \\
\text { convenience } \\
\text { storage, special } \\
\text { tools, and } \\
\text { equipment } \\
\text { financial and } \\
\text { non-financial } \\
\text { controlled }\end{array}$ & 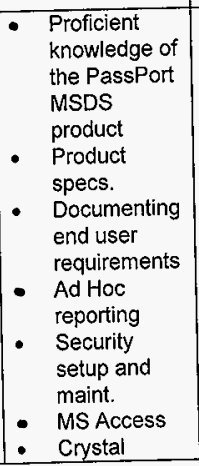 & $\begin{array}{l}\text { INV-001 } \\
\text { Course No. } \\
085040 \\
\text { PassPort } \\
\text { Inventory Mgt. for } \\
\text { Inventory Mgt. } \\
\text { Specialists. }\end{array}$ & Yes & $\begin{array}{l}\text { Systems Basics } \\
\text { Portal/97 CBT }\end{array}$ & $\begin{array}{l}\text { Shari Bultena } \\
\text { (inventory mgt.) } \\
\text { Kim Schultz } \\
\text { (purchasing) } \\
\text { Böb Allen } \\
\text { (vendors) }\end{array}$ & $\begin{array}{l}\text { Approve new } \\
\text { Master Catalog } \\
\text { ID's } \\
\text { Cycle Count } \\
\text { Variance } \\
\text { Approval }\end{array}$ \\
\hline
\end{tabular}


IANDI 2000

OC ITEM: Security Administration Plan HNF- 2713, Rev.0

JATE: $09 / 15 / 98$

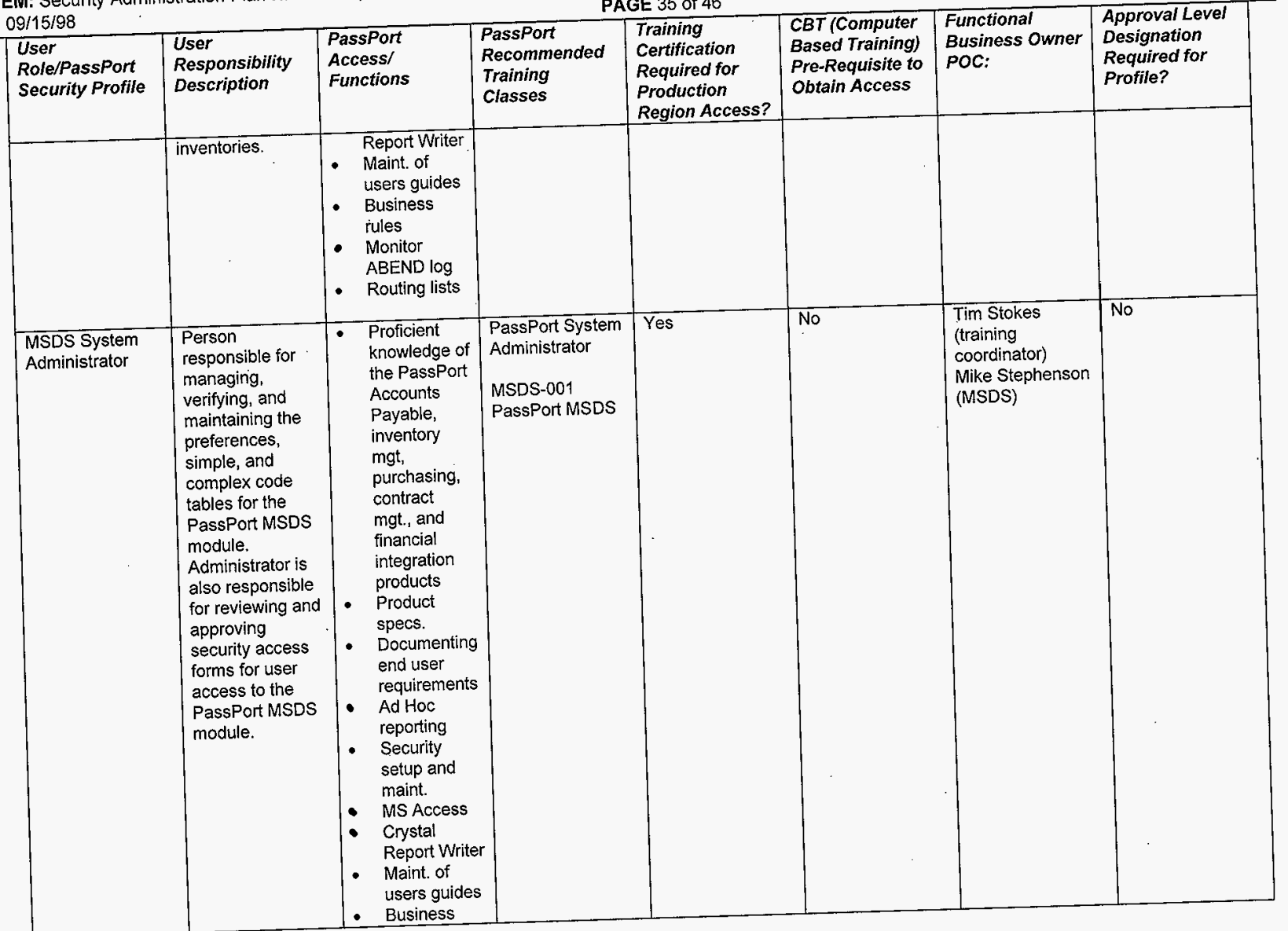


OC ITEM: Security Administration Plan HNF- 2713, Rev.0

ATE: $09 / 15 / 98$

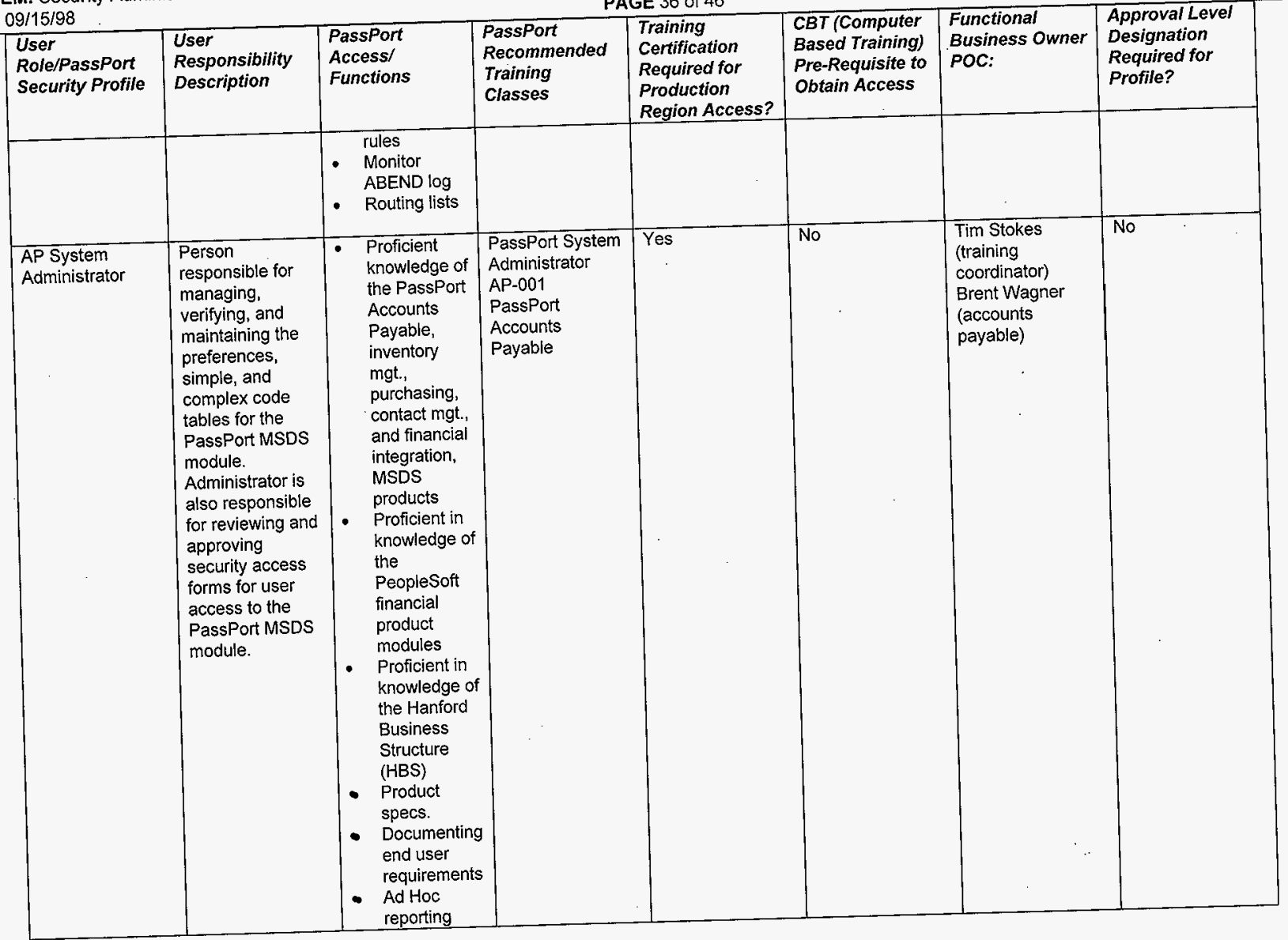


JOC ITEM: Security Administration Plan HNF- 2713, Rev.0

DATE: $09 / 15 / 98$

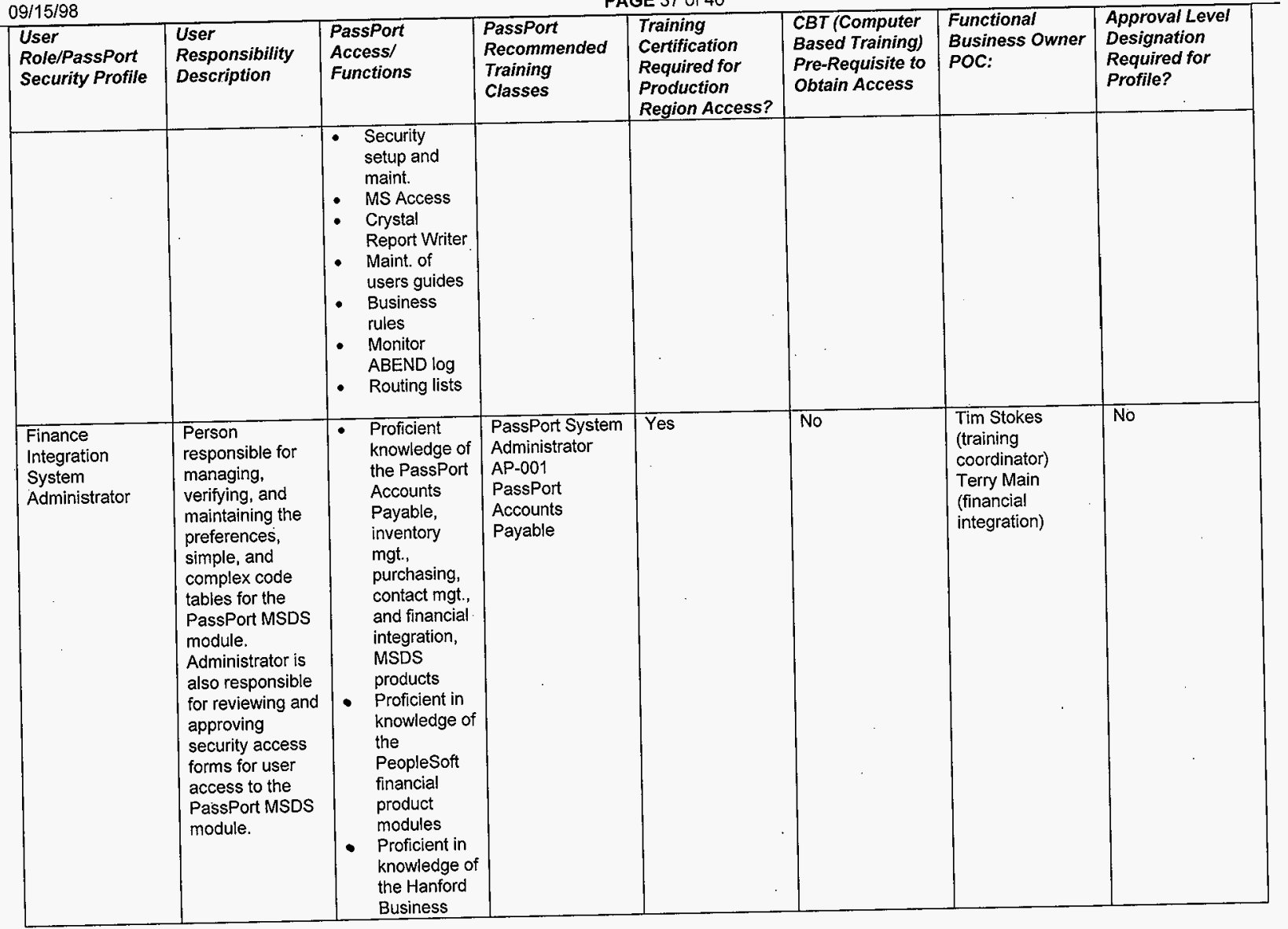


JOC ITEM: Security Administration Plan HNF- 2713, Rev.0

JATE: $09 / 15 / 98$

PAGE 38 of 46

\begin{tabular}{|c|c|c|c|c|c|c|c|}
\hline $\begin{array}{l}\text { User } \\
\text { Role/PassPort } \\
\text { Security Profile }\end{array}$ & $\begin{array}{l}\text { User } \\
\text { Responsibility } \\
\text { Description }\end{array}$ & $\begin{array}{l}\text { PassPort } \\
\text { Access/ } \\
\text { Functions }\end{array}$ & $\begin{array}{l}\text { PassPort } \\
\text { Recommended } \\
\text { Training } \\
\text { Classes } \\
\end{array}$ & $\begin{array}{l}\text { Training } \\
\text { Certification } \\
\text { Required for } \\
\text { Production } \\
\text { Region Access? }\end{array}$ & $\begin{array}{l}\text { CBT (Computer } \\
\text { Based Training) } \\
\text { Pre-Requisite to } \\
\text { Obtain Access }\end{array}$ & $\begin{array}{l}\text { Functional } \\
\text { Business Owner } \\
\text { POC: }\end{array}$ & $\begin{array}{l}\text { Approval Level } \\
\text { Designation } \\
\text { Required for } \\
\text { Profile? }\end{array}$ \\
\hline . & . & \begin{tabular}{|l|} 
Structure \\
(HBS) \\
- Product \\
specs. \\
Documenting \\
end user \\
requirements \\
- Ad Hoc \\
reporting \\
Security \\
setup and \\
maint. \\
MS Access \\
Crystal \\
Report Writer \\
- Maint. of \\
users guides \\
Business \\
rules \\
Monitor \\
ABEND log \\
Routing lists
\end{tabular} & & & & & \\
\hline $\begin{array}{l}\text { Purchasing and } \\
\text { Contract Mgt. } \\
\text { System } \\
\text { Administrator }\end{array}$ & $\begin{array}{l}\text { Person } \\
\text { responsible for } \\
\text { managing, } \\
\text { verifying, and } \\
\text { maintaining the } \\
\text { preferences, } \\
\text { simple, and } \\
\text { complex code } \\
\text { tables for the } \\
\text { PassPort } \\
\text { Purchasing and } \\
\text { Contract Mgt. } \\
\text { Modules. } \\
\text { Administrator is } \\
\text { also responsible } \\
\end{array}$ & $\begin{array}{l}\text { Proficient } \\
\text { knowledge of } \\
\text { the PassPort } \\
\text { Accounts } \\
\text { Payable, } \\
\text { inventory } \\
\text { mgt., } \\
\text { purchasing, } \\
\text { contract } \\
\text { mgt., and } \\
\text { financial } \\
\text { integration, } \\
\text { MSDS } \\
\text { products } \\
\text { Proficient in } \\
\end{array}$ & \begin{tabular}{|l|} 
PassPort System \\
Administrator \\
\\
PUR-003 \\
Course No. \\
085020 \\
PassPort \\
Purchasing \\
Workshop for \\
Buyers \\
CON-004 \\
Course No. \\
085025 \\
PassPort \\
Contract \\
\end{tabular} & Yes & No & $\begin{array}{l}\text { Tim Stokes } \\
\text { (training } \\
\text { coordinator) } \\
\text { Kim Schultz } \\
\text { (purchasing and } \\
\text { contract mgt.) }\end{array}$ & No \\
\hline
\end{tabular}


DOC ITEM: Security Administration Plan HNF- 2713, Rev.0 DATE: $09 / 15 / 98$

PAGE 39 of 46

\begin{tabular}{|c|c|c|c|c|c|c|c|}
\hline $\begin{array}{l}\text { User } \\
\text { Role/PassPort } \\
\text { Security Profile }\end{array}$ & $\begin{array}{l}\text { User } \\
\text { Responsibility } \\
\text { Description }\end{array}$ & $\begin{array}{l}\text { PassPort } \\
\text { Access/ } \\
\text { Functions }\end{array}$ & $\begin{array}{l}\text { PassPort } \\
\text { Recommended } \\
\text { Training } \\
\text { Classes }\end{array}$ & $\begin{array}{l}\text { Training } \\
\text { Certification } \\
\text { Required for } \\
\text { Production } \\
\text { Region Access? } \\
\end{array}$ & $\begin{array}{l}\text { CBT (Computer } \\
\text { Based Training) } \\
\text { Pre-Requisite to } \\
\text { Obtain Access }\end{array}$ & $\begin{array}{l}\text { Functional } \\
\text { Business Owner } \\
\text { POC: }\end{array}$ & $\begin{array}{l}\text { Approval Level } \\
\text { Designation } \\
\text { Required for } \\
\text { Profile? }\end{array}$ \\
\hline & $\begin{array}{l}\text { for reviewing and } \\
\text { approving } \\
\text { security access } \\
\text { forms for user } \\
\text { access to the } \\
\text { PassPort MSDS } \\
\text { module. }\end{array}$ & $\begin{array}{l}\text { knowledge of } \\
\text { the } \\
\text { PeopleSoft } \\
\text { financial } \\
\text { product } \\
\text { modules } \\
\text { - Proficient in } \\
\text { knowledge of } \\
\text { the Hanford } \\
\text { Business } \\
\text { Structure } \\
\text { (HBS) } \\
\text { Product } \\
\text { specs. } \\
\text { Documenting } \\
\text { end user } \\
\text { requirements } \\
\text { Ad Hoc } \\
\text { reporting } \\
\text { Security } \\
\text { setup and } \\
\text { maint. } \\
\text { MS Access } \\
\text { Crystal } \\
\text { Report Writer } \\
\text { Maint. of } \\
\text { users guides } \\
\text { Business } \\
\text { rules } \\
\text { Monitor } \\
\text { ABEND log } \\
\text { Routing lists }\end{array}$ & $\begin{array}{l}\text { Administration for } \\
\text { Contract } \\
\text { Administrators }\end{array}$ & 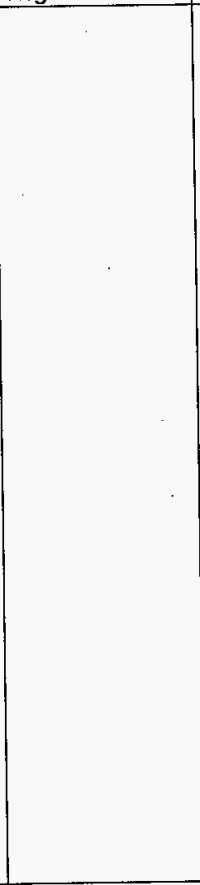 & & & . \\
\hline $\begin{array}{l}\text { Inventory Mgt. } \\
\text { System } \\
\text { Administrator }\end{array}$ & $\begin{array}{l}\text { Person } \\
\text { responsible for } \\
\text { managing, } \\
\text { verifying, and } \\
\text { maintaining the } \\
\end{array}$ & $\begin{array}{l}\text { Proficient } \\
\text { knowledge of } \\
\text { the PassPort } \\
\text { Accounts } \\
\text { Payable, } \\
\end{array}$ & $\begin{array}{l}\text { PassPort System } \\
\text { Administrator } \\
\text { INV-001 } \\
\text { Course No. }\end{array}$ & Yes & Yes & $\begin{array}{l}\text { Tim Stokes } \\
\text { (training } \\
\text { coordinator) } \\
\text { Shari Bultena } \\
\text { and Paulette } \\
\end{array}$ & No \\
\hline
\end{tabular}


1OC ITEM: Security Administration Plan HNF- 2713, Rev.0 IATE: $09 / 15 / 98$

\begin{tabular}{|c|c|c|c|c|c|c|c|}
\hline $\begin{array}{l}\text { User } \\
\text { Role/PassPort } \\
\text { Security Profile }\end{array}$ & $\begin{array}{l}\text { User } \\
\text { Responsibility } \\
\text { Description }\end{array}$ & $\begin{array}{l}\text { PassPort } \\
\text { Access/ } \\
\text { Functions }\end{array}$ & $\begin{array}{l}\text { PassPort } \\
\text { Recommended } \\
\text { Training } \\
\text { Classes }\end{array}$ & $\begin{array}{l}\text { Training } \\
\text { Certification } \\
\text { Required for } \\
\text { Production } \\
\text { Region Access? }\end{array}$ & $\begin{array}{l}\text { CBT (Computer } \\
\text { Based Training) } \\
\text { Pre-Requisite to } \\
\text { Obtain Access }\end{array}$ & $\begin{array}{l}\text { Functional } \\
\text { Business Owner } \\
\text { POC: }\end{array}$ & $\begin{array}{l}\text { Approval Level } \\
\text { Designation } \\
\text { Required for } \\
\text { Profile? }\end{array}$ \\
\hline . & $\begin{array}{l}\text { preferences, } \\
\text { simple, and } \\
\text { complex code } \\
\text { tables for the } \\
\text { PassPort } \\
\text { Inventory Mgt. } \\
\text { module. } \\
\text { Administrator is } \\
\text { also responsible } \\
\text { for reviewing and } \\
\text { approving } \\
\text { security access } \\
\text { forms for user } \\
\text { access to the } \\
\text { PassPort MSDS } \\
\text { module. }\end{array}$ & $\begin{array}{l}\text { inventory } \\
\text { mgt., } \\
\text { purchasing, } \\
\text { contract } \\
\text { mgt., and } \\
\text { financial } \\
\text { integration, } \\
\text { MSDS } \\
\text { products } \\
\text { Proficient in } \\
\text { knowledge of } \\
\text { the } \\
\text { PeopleSoft } \\
\text { financial } \\
\text { product } \\
\text { modules } \\
\text { Proficient in } \\
\text { knowledge of } \\
\text { the Hanford } \\
\text { Business } \\
\text { Structure } \\
\text { (HBS) } \\
\text { Product } \\
\text { specs. } \\
\text { Documenting } \\
\text { end user } \\
\text { requirements } \\
\text { Ad Hoc } \\
\text { reporting } \\
\text { Security } \\
\text { usetup and } \\
\text { maint. of } \\
\text { MS Access } \\
\text { Report Writer } \\
\text { - } \\
\text { - } \\
\text { - } \\
\text { - } \\
\text { - }\end{array}$ & $\begin{array}{l}085040 \\
\text { PassPort } \\
\text { Inventory Mgt. for } \\
\text { Inventory Mgt. } \\
\text { Specialists }\end{array}$ & - & . & $\begin{array}{l}\text { White (inventory } \\
\text { mgt.) }\end{array}$ & - \\
\hline
\end{tabular}


DOC ITEM: Security Administration Plan HNF- 2713, Rev.0

DATE: $09 / 15 / 98$

\begin{tabular}{|l|l|l|l|l|l|l|l|}
$\begin{array}{l}\text { User } \\
\text { Role/PassPort } \\
\text { Security Profile }\end{array}$ & $\begin{array}{l}\text { User } \\
\text { Responsibility } \\
\text { Description }\end{array}$ & $\begin{array}{l}\text { PassPort } \\
\text { Access/ } \\
\text { Functions }\end{array}$ & $\begin{array}{l}\text { PassPort } \\
\text { Recommended } \\
\text { Training } \\
\text { Classes }\end{array}$ & $\begin{array}{l}\text { Training } \\
\text { Certification } \\
\text { Required for } \\
\text { Production } \\
\text { Region Access? }\end{array}$ & $\begin{array}{l}\text { CBT (Computer } \\
\text { Based Training) } \\
\text { Pre-Requisite to } \\
\text { Obtain Access }\end{array}$ & $\begin{array}{l}\text { Functional } \\
\text { Business Owner } \\
\text { POC: }\end{array}$ & $\begin{array}{l}\text { Approval Level } \\
\text { Designation } \\
\text { Required for } \\
\text { Profile? }\end{array}$ \\
\hline & & $\begin{array}{l}\text { rules } \\
\text { Monitor } \\
\text { ABEND log } \\
\text { Routing lists }\end{array}$ & & & & \\
\hline
\end{tabular}




\begin{tabular}{|c|c|c|c|c|c|c|c|}
\hline $\begin{array}{l}\text { User Role/HRIS } \\
\text { Security Profile }\end{array}$ & $\begin{array}{l}\text { User } \\
\text { Responsibility } \\
\text { Description }\end{array}$ & $\begin{array}{l}\text { HRIS Access/ } \\
\text { Functions } \\
\end{array}$ & $\begin{array}{l}\text { HRIS } \\
\text { Recommended } \\
\text { Training } \\
\text { Classes }\end{array}$ & $\begin{array}{l}\text { Training } \\
\text { Certification } \\
\text { Required for } \\
\text { Production } \\
\text { Region Access? }\end{array}$ & $\begin{array}{l}\text { CBT (Computer } \\
\text { Based Training) } \\
\text { Pre-Requisite to } \\
\text { Obtain Access }\end{array}$ & $\begin{array}{l}\text { Functional } \\
\text { Business Owner } \\
\text { POC: }\end{array}$ & $\begin{array}{l}\text { Approval Level } \\
\text { Designation } \\
\text { Required for } \\
\text { Profile? }\end{array}$ \\
\hline $\begin{array}{l}\text { Personnel } \\
\text { Records Update } \\
\text { User }\end{array}$ & $\begin{array}{l}\text { Update employee } \\
\text { and job change } \\
\text { information. } \\
\text { Update hires, } \\
\text { terminations, } \\
\text { department } \\
\text { changes. }\end{array}$ & 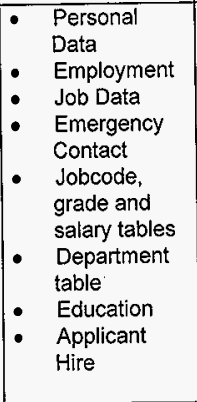 & \begin{tabular}{|ll} 
- & Intro to HR \\
& Into to \\
& Benefits \\
- & Crystal \\
& Reporting \\
- & Query \\
- & PS/n Vision \\
- Process \\
Scheduler \\
- Recruitment \\
- Position \\
Management
\end{tabular} & None & None & Becky Calapristi & $\begin{array}{l}\text { HR Security } \\
\text { Access } \\
\text { Administrator } \\
\text { Approval and/or } \\
\text { HR Management }\end{array}$ \\
\hline Benefits User & $\begin{array}{l}\text { Use and maintain } \\
\text { employee } \\
\text { insurance } \\
\text { eligibility and } \\
\text { options. }\end{array}$ & 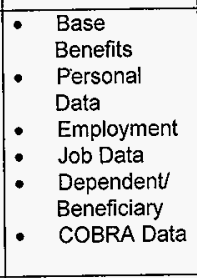 & $\begin{array}{ll}- & \text { Intro to HR } \\
\text { - } & \text { Intro to } \\
& \text { Benefits } \\
\text { - } & \text { Intro to } \\
& \text { Payroll } \\
\text { - } & \text { Crystal } \\
& \text { Reporting }\end{array}$ & None & None & Becky Calapristi & $\begin{array}{l}\text { HR Security } \\
\text { Access } \\
\text { Administrator } \\
\text { Approval and/or } \\
\text { HR Management }\end{array}$ \\
\hline $\begin{array}{l}\text { COBRA - } \\
\text { Inactive } \\
\text { Employee } \\
\text { Insurance } \\
\text { Maintenance }\end{array}$ & $\begin{array}{l}\text { Maintain the } \\
\text { insurance } \\
\text { coverage of } \\
\text { inactive } \\
\text { employees. }\end{array}$ & $\begin{array}{ll}\text { - } & \text { Administer } \\
\text { COBRA } \\
\text { Benefits } \\
\text { Billing }\end{array}$ & 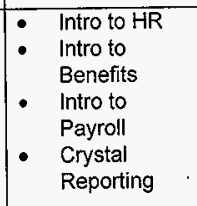 & None & None & Becky Calapristi & $\begin{array}{l}\text { HR Security } \\
\text { Access } \\
\text { Administrator } \\
\text { Approval and/or } \\
\text { HR Management }\end{array}$ \\
\hline
\end{tabular}


DOC ITEM: Security Administration Plan HNF- 2713, Rev.0 DATE: $09 / 15 / 98$

\begin{tabular}{|c|c|c|c|c|c|c|c|}
\hline $\begin{array}{l}\text { User Role/HRIS } \\
\text { Security Profile }\end{array}$ & $\begin{array}{l}\text { User } \\
\text { Responsibility } \\
\text { Description }\end{array}$ & $\begin{array}{l}\text { HRIS Access/ } \\
\text { Functions }\end{array}$ & $\begin{array}{l}\text { HRIS } \\
\text { Recommended } \\
\text { Training } \\
\text { Classes }\end{array}$ & $\begin{array}{l}\text { Training } \\
\text { Certification } \\
\text { Required for } \\
\text { Production } \\
\text { Region Access? }\end{array}$ & $\begin{array}{l}\text { CBT (Computer } \\
\text { Based Training) } \\
\text { Pre-Requisite to } \\
\text { Obtain Access }\end{array}$ & $\begin{array}{l}\text { Functional } \\
\text { Business Owner } \\
\text { POC: }\end{array}$ & $\begin{array}{l}\text { Approval Level } \\
\text { Designation } \\
\text { Required for } \\
\text { Profile? }\end{array}$ \\
\hline $\begin{array}{l}\text { Pension \& } \\
\text { Savings User }\end{array}$ & $\begin{array}{l}\text { Identify pension } \\
\text { and retirement } \\
\text { eligibility and } \\
\text { benefit for } \\
\text { employee. }\end{array}$ & $\begin{array}{l}\text { Personal } \\
\text { Data } \\
\text { - Employment } \\
\text { - Job Data }\end{array}$ & $\begin{array}{l}\text { - } \quad \text { intro to HR } \\
\text { - Crystal } \\
\text { Reporting }\end{array}$ & None & None & Becky Calapristi & $\begin{array}{l}\text { HR Security } \\
\text { Access } \\
\text { Administrator } \\
\text { Approval and/or } \\
\text { HR Management }\end{array}$ \\
\hline EEO User & $\begin{array}{l}\text { Report EEO and } \\
\text { Affirmative Action } \\
\text { goals and status. }\end{array}$ & $\begin{array}{ll}\text { - } & \text { EEO Status } \\
\text { Personal } \\
\text { Data } \\
\text { - } & \text { Employment } \\
\text { - } & \text { Job Data } \\
\text { Competency } \\
\text { - Management } \\
\text { Career/ } \\
\text { Succession } \\
\text { Planning }\end{array}$ & $\begin{array}{ll}\text { - } & \text { Intro to HR } \\
\text { - } & \text { Crystal } \\
\text { Reporting } \\
\text { Career/ } \\
\text { Succession } \\
\text { Planning } \\
\text { Competency } \\
\text { Management }\end{array}$ & None & None & Becky Calapristi & $\begin{array}{l}\text { HR Security } \\
\text { Access } \\
\text { Administrator } \\
\text { Approval and/or } \\
\text { HR Management }\end{array}$ \\
\hline $\begin{array}{l}\text { HR Service } \\
\text { Provider }\end{array}$ & $\begin{array}{l}\text { View and report } \\
\text { employee job } \\
\text { history, } \\
\text { compensation } \\
\text { and disability. } \\
\text { Update and } \\
\text { maintain } \\
\text { recruiting activity. } \\
\text { Provide update } \\
\text { direction to HR } \\
\text { personnel } \\
\text { records update } \\
\text { users. }\end{array}$ & $\begin{array}{ll}\text { - } & \text { Applicants, } \\
\text { job } \\
\text { requisitions, } \\
\text { recruiting } \\
\text { Personal } \\
\text { Data } \\
\text { - Employment } \\
\text { - Job } \\
\text { - Salary } \\
\text { Planning } \\
\text { Base } \\
\text { Benefits } \\
\text { Set up HGET } \\
\text { training } \\
\text { Competency } \\
\text { Management } \\
\text { Position } \\
\text { Management }\end{array}$ & $\begin{array}{ll}\text { - } & \text { Intro to HR } \\
\text { - } & \text { Intro to } \\
& \text { Benefits } \\
\text { - } & \text { Crystal } \\
& \text { Reporting } \\
\text { - } & \text { Planning } \\
& \text { Compensatio } \\
\text { - } & \text { Position } \\
\text { - Management } \\
\text { - } \text { RSin Vision } \\
\text { Recruitment }\end{array}$ & None & None & Becky Calapristi & $\begin{array}{l}\text { HR Security } \\
\text { Access } \\
\text { Administrator } \\
\text { Approval and/or } \\
\text { HR Management }\end{array}$ \\
\hline
\end{tabular}


OOC ITEM: Security Administration Plan HNF- 2713, Rev.0 ATE: $09 / 15 / 98$

\begin{tabular}{|c|c|c|c|c|c|c|c|}
\hline $\begin{array}{l}\text { User Role/HRIS } \\
\text { Security Profile }\end{array}$ & $\begin{array}{l}\text { User } \\
\text { Responsibility } \\
\text { Description }\end{array}$ & $\begin{array}{l}\text { HRIS Access/ } \\
\text { Functions }\end{array}$ & $\begin{array}{l}\text { HRIS } \\
\text { Recommended } \\
\text { Training } \\
\text { Classes }\end{array}$ & $\begin{array}{l}\text { Training } \\
\text { Certification } \\
\text { Required for } \\
\text { Production } \\
\text { Region Access? } \\
\end{array}$ & $\begin{array}{l}\text { CBT (Computer } \\
\text { Based Training) } \\
\text { Pre-Requisite to } \\
\text { Obtain Access }\end{array}$ & $\begin{array}{l}\text { Functional } \\
\text { Business Owner } \\
\text { POC: }\end{array}$ & $\begin{array}{l}\text { Approval Level } \\
\text { Designation } \\
\text { Required for } \\
\text { Profile? }\end{array}$ \\
\hline $\begin{array}{l}\text { HR } \\
\text { Subcontractor } \\
\text { User }\end{array}$ & $\begin{array}{l}\text { View and report } \\
\text { compensation, } \\
\text { employee job } \\
\text { history, disability } \\
\text { and recruiting } \\
\text { activity. }\end{array}$ & $\begin{array}{ll}\text { - } & \text { Applicants, } \\
& \text { job } \\
& \text { requisitions, } \\
& \text { recruiting } \\
\text { - Personal } & \text { Data } \\
\text { - } & \text { Employment } \\
\text { - Job }\end{array}$ & $\begin{array}{ll}- & \text { Intro to HR } \\
\text { - } & \text { Crystal } \\
& \text { Reporting } \\
\text { - } & \text { Recruitment }\end{array}$ & None & None & Becky Calapristi & $\begin{array}{l}\text { HR Security } \\
\text { Access } \\
\text { Administrator } \\
\text { Approval and/or } \\
\text { HR Management }\end{array}$ \\
\hline $\begin{array}{l}\text { HR System } \\
\text { Functional } \\
\text { Administrator }\end{array}$ & $\begin{array}{l}\text { Identify and } \\
\text { maintain } \\
\text { appropriate } \\
\text { security access } \\
\text { for users. Map } \\
\text { data for system } \\
\text { upgrades. Test } \\
\text { software } \\
\text { changes. Define } \\
\text { user } \\
\text { requirements. } \\
\text { Provide training } \\
\text { and help for } \\
\text { database users. } \\
\text { Set up and define } \\
\text { new system } \\
\text { functionality. } \\
\text { Maintain } \\
\text { production } \\
\text { reports and } \\
\text { system } \\
\text { interfaces. }\end{array}$ & $\begin{array}{l}\text { All HR } \\
\text { panels and } \\
\text { tables } \\
\text { Overall HR } \\
\text { security } \\
\text { access } \\
\text { Manage } \\
\text { database } \\
\text { changes }\end{array}$ & 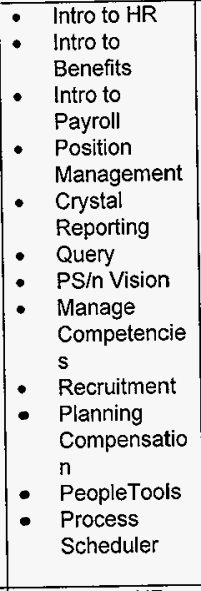 & None & None & Becky Calapristi & $\begin{array}{l}\text { HR Security } \\
\text { Access } \\
\text { Administrator } \\
\text { Approval and/or } \\
\text { HR Management }\end{array}$ \\
\hline Payroll User & $\begin{array}{l}\text { Maintain payroll } \\
\text { tables. For } \\
\text { example, taxing, } \\
\text { insurance, } \\
\text { additional pay, } \\
\text { earnings and } \\
\text { deductions etc. }\end{array}$ & $\begin{array}{ll}-\quad \text { Base } \\
& \text { Benefits } \\
\therefore \quad & \text { Tax Tables } \\
& \text { Payroll } \\
& \text { Tables } \\
- & \text { Personal } \\
& \text { Data }\end{array}$ & $\begin{array}{ll}\text { - Intro to HR } \\
\text { Intro to } \\
\text { Benefits } \\
\text { Intro to } \\
\text { Payroll } \\
\text { Crystal } \\
\text { Reporting }\end{array}$ & None & None & Didi Staudacher & $\begin{array}{l}\text { PayrollSecurity } \\
\text { Access } \\
\text { Administrator } \\
\text { Approval andior } \\
\text { Payroll } \\
\text { Management }\end{array}$ \\
\hline
\end{tabular}


HANDI 2000

DOC ITEM: Security Administration Plan HNF- 2713, Rev.0 DATE: $09 / 15 / 98$

PAGE 45 of 46

\begin{tabular}{|c|c|c|c|c|c|c|c|}
\hline $\begin{array}{l}\text { User Role/HRIS } \\
\text { Security Profile }\end{array}$ & $\begin{array}{l}\text { User } \\
\text { Responsibility } \\
\text { Description }\end{array}$ & $\begin{array}{l}\text { HRIS Access/ } \\
\text { Functions }\end{array}$ & $\begin{array}{l}\text { HRIS } \\
\text { Recommended } \\
\text { Training } \\
\text { Classes }\end{array}$ & $\begin{array}{l}\text { Training } \\
\text { Certification } \\
\text { Required for } \\
\text { Production } \\
\text { Region Access? } \\
\end{array}$ & $\begin{array}{l}\text { CBT (Computer } \\
\text { Based Training) } \\
\text { Pre-Requisite to } \\
\text { Obtain Access }\end{array}$ & $\begin{array}{l}\text { Functional } \\
\text { Business Owner } \\
\text { POC: }\end{array}$ & $\begin{array}{l}\text { Approval Level } \\
\text { Designation } \\
\text { Required for } \\
\text { Profile? }\end{array}$ \\
\hline & & $\begin{array}{ll}\text { - } & \text { Employment } \\
\text { - Job }\end{array}$ & & & & & \\
\hline $\begin{array}{l}\text { Payroll System } \\
\text { Functional } \\
\text { Administrator }\end{array}$ & $\begin{array}{l}\text { Identify and } \\
\text { maintain } \\
\text { appropriate } \\
\text { security access } \\
\text { for users. Map } \\
\text { data for system } \\
\text { upgrades. Test } \\
\text { software } \\
\text { changes. Define } \\
\text { user } \\
\text { requirements. } \\
\text { Provide training } \\
\text { and help for } \\
\text { database users. } \\
\text { Set up and define } \\
\text { new system } \\
\text { functionality. } \\
\text { Maintain } \\
\text { production } \\
\text { reports and } \\
\text { system } \\
\text { interfaces. }\end{array}$ & $\begin{array}{l}\text { - All Payroll } \\
\text { panels and } \\
\text { tables } \\
\text { Overall } \\
\text { Payroll } \\
\text { security } \\
\text { access } \\
\text { Manage } \\
\text { database } \\
\text { changes }\end{array}$ & $\begin{array}{ll} & \text { Intro to HR } \\
\text { - } & \text { Intro to } \\
& \text { Benefits } \\
\text { - } & \text { Intro to } \\
& \text { Payroll } \\
\text { - } & \text { Adv Payroll } \\
\text { - } & \text { PeopleTools } \\
\text { - PSin Vision } \\
\text { - } & \text { Payroll Year- } \\
& \text { End }\end{array}$ & None & None & Didi Staudacher & $\begin{array}{l}\text { Payroll Security } \\
\text { Access } \\
\text { Administrator } \\
\text { Approval and/or } \\
\text { Payroll } \\
\text { Management }\end{array}$ \\
\hline Training User & $\begin{array}{l}\text { Schedule and } \\
\text { register } \\
\text { employees into } \\
\text { training courses. } \\
\text { Bill departments } \\
\text { for classes taken. } \\
\text { Update training } \\
\text { requirements. }\end{array}$ & \begin{tabular}{|l} 
- \\
Scheduling \\
and \\
registration. \\
TMX \\
- Course \\
Billing \\
Completed \\
Training \\
\end{tabular} & $\begin{array}{ll}\text { - } & \text { Crystal } \\
& \text { Reporting }\end{array}$ & None & None & Lucy Reed & $\begin{array}{l}\text { Training Security } \\
\text { Access } \\
\text { Administrator } \\
\text { Approval and/or } \\
\text { Training } \\
\text { Management }\end{array}$ \\
\hline
\end{tabular}


DOC ITEM: Security Administration Plan HNF- 2713, Rev.0

DATE: $09 / 15 / 98$

\begin{tabular}{|c|c|c|c|c|c|c|c|}
\hline $\begin{array}{l}\text { User Role/HRIS } \\
\text { Security Profile }\end{array}$ & $\begin{array}{l}\text { User } \\
\text { Responsibility } \\
\text { Description }\end{array}$ & $\begin{array}{l}\text { HRIS Access/ } \\
\text { Functions }\end{array}$ & $\begin{array}{l}\text { HRIS } \\
\text { Recommended } \\
\text { Training } \\
\text { Classes }\end{array}$ & $\begin{array}{l}\text { Training } \\
\text { Certification } \\
\text { Required for } \\
\text { Production } \\
\text { Region Access? } \\
\end{array}$ & $\begin{array}{l}\text { CBT (Computer } \\
\text { Based Training) } \\
\text { Pre-Requisite to } \\
\text { Obtain Access }\end{array}$ & $\begin{array}{l}\text { Functional } \\
\text { Business Owner } \\
\text { POC: }\end{array}$ & $\begin{array}{l}\text { Approval Level } \\
\text { Designation } \\
\text { Required for } \\
\text { Profile? }\end{array}$ \\
\hline . & $\begin{array}{l}\text { Run completed } \\
\text { training reports. }\end{array}$ & Reports & & & & & \\
\hline $\begin{array}{l}\text { Training System } \\
\text { Functional } \\
\text { Administrator }\end{array}$ & $\begin{array}{l}\text { Identify and } \\
\text { maintain } \\
\text { appropriate } \\
\text { security access } \\
\text { for users. Map } \\
\text { data for system } \\
\text { upgrades. Test } \\
\text { software } \\
\text { changes. Define } \\
\text { user } \\
\text { requirements. } \\
\text { Provide training } \\
\text { and help for } \\
\text { database users. } \\
\text { Set up and define } \\
\text { new system } \\
\text { functionality. } \\
\text { Maintain } \\
\text { production } \\
\text { reports and } \\
\text { system } \\
\text { interfaces. }\end{array}$ & $\begin{array}{l}\text { All training } \\
\text { panels and } \\
\text { tables } \\
\text { Overall } \\
\text { training } \\
\text { security } \\
\text { access } \\
\text { Manage } \\
\text { database } \\
\text { changes }\end{array}$ & $\begin{array}{ll}\text { - } & \text { Intro to HR } \\
\text { - } & \text { Crystal } \\
& \text { Reporting } \\
\text { - } & \text { PS/n Vision } \\
\text { - } & \text { PeopleTools }\end{array}$ & None & None & Lucy Reed & $\begin{array}{l}\text { Training Security } \\
\text { Access } \\
\text { Administrator } \\
\text { Approval and/or } \\
\text { Training } \\
\text { Management }\end{array}$ \\
\hline
\end{tabular}

